ISSN: 0213-2079 - ISSN electrónico: 2386-3889

DOI: https://doi.org/10.14201/shhmo2020422365400

\title{
INFIDELIDAD Y PUNICIÓN. CABALLEROS Y FREILES AUSTRACISTAS ANTE EL TRIBUNAL DE LA LUGARTE- NENCIA GENERAL DE MONTESA ${ }^{1}$
}

\section{Infidelity and Punishment. Austracists Knights and Friars before the Court of the Lieutenant General of Montesa}

\author{
María SALAS BENEDITO \\ Universitat de València \\ Maria.Salas@uv.es
}

Fecha de recepción: 28/03/2020

Fecha de aceptación: 23/09/2020

RESUMEN: El presente artículo se propone analizar el austracismo dentro de la Orden de Montesa a través de la documentación procesal existente contra sus caballeros y religiosos. Mediante el estudio de los diferentes casos, quedan al descubierto no solo las trayectorias de algunos de los principales austracistas valencianos, sino también el modo en que la Orden castigó la disidencia, entre otros aspectos. Todo esto nos permite observar cuales fueron los caminos seguidos por estos personajes antes, durante y después del conflicto sucesorio, de forma que podamos establecer una caracterización general del grupo al mismo tiempo que constatar cada una de sus singularidades.

1. Este trabajo se ha realizado gracias a un contrato predoctoral VALi+d financiado por la Generalitat Valenciana y el Fondo Social Europeo y enmarcado dentro del proyecto de Investigación financiado por el Ministerio de Economía y Competitividad «Privilegio, trabajo y conflictividad. La sociedad moderna de los territorios hispánicos del mediterráneo occidental entre el cambio y las resistencias» (PGC2018-094150-B-C21). 
MARIA SALAS BENEDITO

INFIDELIDAD Y PUNICIÓN. CABALLEROS Y FREILES AUSTRACISTAS

ANTE EL TRIBUNAL DE LA LUGARTENENCIA GENERAL DE MONTESA

Palabras clave: Austracistas; Orden de Montesa; Guerra de Sucesión Española; Reino de Valencia.

ABSTRACT: This paper intends to analyse the austracism within the Order of Montesa through the existing procedural documentation against their knights and friars. With the study of the different cases, not only the trajectories of some of the main austracists from Valencia are discovered, but also the the way in which the Order punished dissent, among other aspects. All these allow us to observe which were the paths followed by these characters before, during and after the succession conflict, so that we can establish general characterisation of the group and, at the same time, highlight each of its singularities.

Keywords: Austracists; Order of Montesa; Spanish Succession War; Kingdom of Valencia.

Sin lugar a dudas la Guerra de Sucesión continúa viéndose como uno de los episodios más controvertidos de la historia de la Monarquía Hispánica y no solamente por las incógnitas que a nivel historiográfico aún quedan por despejar, sino también por la complejidad que supone para el investigador entender las motivaciones de los diferentes agentes que, pertenecientes a todos los estratos sociales, ejercieron una actividad importante a favor de cada uno de los bandos. Aun así, el tema ha despertado el interés de numerosos estudiosos y ha sido analizado desde diferentes puntos de vista: estrategias y actuaciones bélicas, proyectos políticos de los pretendientes, posicionamiento de los reinos y sus pobladores, y un largo etcétera. ${ }^{2}$ En este contexto historiográfico el presente trabajo pretende abordar el análisis del posicionamiento austracista dentro de la Orden de Montesa y acentuar el papel de estos personajes al servicio del Archiduque, dado que muchos de ellos ocuparon cargos de relevancia tanto a nivel político y territorial como en el ámbito militar. Evidentemente la Guerra de Sucesión se convirtió en un conflicto civil y, como tal,

2. Ciertamente ha sido un tema abordado por muchos autores desde diferentes vertientes, ya sea el apoyo «mayoritario» de uno de los reinos (Muñoz, 2007: 171-195; Ragón, 1984: 225-232; Pérez, 2004: 119-149; Sánchez, 2007: 257-302), la de un grupo social o institución en concreto (Chiquillo, 1991: 115-148; León, 2008: 239-263; Solís, 2005: 131-150), o la represión vehiculada a través del exilio y el secuestro de los bienes y su trayectoria tras finalizar la contienda (Alcoberro, 2002; Léon, 1997: 469-500; 2007: 235-256; 2014, 195-237; Pérez y Felipo, 1998: 329-343). Por otro lado, el conflicto sucesorio también comportó modificaciones en la vertiente institucional de la Orden de Montesa (Andrés, 1994: 37-47; 2012: 255-274).

Ediciones Universidad de Salamanca / @®@@ Stud. his., H. ${ }^{a}$ mod., 42, n. 2 (2020), pp. 365-400 
dividió a la sociedad. En este sentido la Orden valenciana no fue una excepción, sobre todo si tenemos en cuenta que el reino se encontró bajo dominio del Austria prácticamente dos años. Por tanto, entre sus miembros encontramos personajes de ambas filiaciones, algunos neutrales y otros con actitudes titubeantes que protagonizaron cambios en su fidelidad a lo largo del conflicto. Aunque, desde luego, el protagonismo de algunos de los caballeros y freiles de la Orden tuvo mucho que ver con que el lugarteniente general del momento, don José de Cardona, fuese un ferviente austracista encumbrado a la posición de virrey valenciano. Ahora bien, su actitud en pos de la causa imperial no fue obviada por las autoridades borbónicas ni quedó impune, sino que muchos de ellos fueron investigados por la Orden y no pocos juzgados y condenados por su infidelidad a Felipe V. Este es el punto más interesante de nuestro trabajo, pues los procesos judiciales a que fueron sometidos nos han aportado información más que relevante para conocer el proceder de muchos de estos individuos y el modo en que fue castigada su disidencia.

Precisamente por su interés, antes de adentrarnos de lleno en nuestra investigación nos gustaría presentar unas breves pinceladas sobre las fuentes utilizadas. La base de nuestro análisis se centra en los procesos judiciales ${ }^{3}$ que la Orden abrió contra sus miembros por austracismo. Esta documentación se encuentra en el Arxiu del Regne de València, en la sección Clero, en su serie Montesa. Suponen un total de 21 expedientes muy ricos en cuanto a la información que contienen, si bien algunos se encuentran inconclusos y resulta complicada su localización. Los procesos se inician con una recepción de testimonios, personas que acuden a declarar sobre las actuaciones que los diferentes miembros de la Orden llevaron a cabo al servicio del Archiduque. Dichos testigos suelen ser vecinos, personas al servicio de los acusados o familiares de estos, aunque en muchos sumarios encontramos como declarantes a individuos que por su filiación borbónica fueron deportados a Barcelona bajo el virreinato de Cardona, por lo que atestiguan también sobre el comportamiento de los inculpados durante su exilio en el Principado. Esta primera parte es una de las más interesantes, ya que aporta una gran cantidad de información acerca de los personajes: cargos, acciones, relaciones entre ellos, etc. El segundo paso, centrado de lleno en la actuación judicial ${ }^{4}$, presenta diferencias entre el grupo de los caballeros

3. Sobre la estructura judicial de la Orden de Montesa ver Hernández, 2014: 121-184.

4. Al hilo de lo expuesto, cabría incluir unas pequeñas pinceladas acerca del contexto político y jurisdiccional de la Orden valenciana. Así, tras la incorporación de la misma a la Corona, fue el lugarteniente general quien reunió amplias funciones gubernativas y contenciosas tanto en el campo de la jurisdicción civil como en el de la criminal. En lo contencioso actuó por medio del tribunal de la lugartenencia, compuesto por el mismo lugarteniente, un abogado fiscal y bien dos asesores civiles de la Real Audiencia, o bien por varios ancianos de la Orden. Este tribunal será el encargado de dirimir los diferentes procesos abiertos en el seno de la Orden, y su estructura jurisdiccional se mantendrá tras la abolición de los Fueros valencianos, lo que

Ediciones Universidad de Salamanca / @®@@ Stud. his., H. ${ }^{a}$ mod., 42, n. 2 (2020), pp. 365-400 
y el de los religiosos. Los primeros no suelen encontrarse en el reino, por lo que resulta vano el intento de arrestarlos. Consecuentemente, el acusado era citado a declarar, aunque rara vez consiguieron que se personara ante el tribunal. Por tanto, tras tres contumacias, el proceso continuaba y se pedía autorización al monarca para que la sentencia fuese publicada, como hicieron tras obtener su beneplácito. Evidentemente, el fallo incluye la condena impuesta al acusado, que mayoritariamente supone la retirada del hábito y las mercedes montesianas, la expedición de una orden de captura para ser privado de su libertad, el secuestro de sus bienes y la obligación de hacer frente a los costes económicos del proceso -satisfechos con los frutos del embargo-. En cambio, los procesos contra los freiles se dirimieron en una cronología más tardía y prácticamente todos ya se encontraban encarcelados, lo que hizo posible la declaración de los acusados. Muchos se hallan sin sentencia, aunque se observa que la condena habitual fue la pena de prisión y la obligación de hacerse cargo de los costes del proceso ${ }^{5}$.

Además, cabe destacar que en un buen número de los procesos hemos encontrado documentación anexa, utilizada como prueba inculpatoria, que suele hacer referencia a designaciones y juramentos de cargos y pagas de salarios, testimonios más que significativos para nuestro objeto de estudio. A nivel documental, la información aportada por los sumarios se complementa con un libro de secuestros ${ }^{6}$ en el que la Orden recogió la información de los bienes embargados a prácticamente todos los caballeros. Por otro lado, también hemos consultado documentación conservada en el Österreichisches Staatsarchiv de Viena, que nos ha aportado importantes noticias sobre algunos de los austracistas que tras el conflicto se exilaron a dominios imperiales. Tratándose sobre todo de memoriales y documentación privada, resulta muy interesante para la profundización en las trayectorias de los diferentes personajes.

\section{DESLEALTAD CASTIGADA. LA OPOSICIÓN A FELIPE V EN SANTA MARÍA DE MONTESA}

Antes de centrarnos en el análisis de los casos, consideramos conveniente presentar una caracterización general sobre los posicionamientos ante el conflicto sucesorio

explica que los religiosos y caballeros montesianos acusados de infidelidad a Felipe $\mathrm{V}$ fuesen investigados, procesados y sentenciados por este tribunal (Andrés, 1994: 38-45).

5. Dado que las condenas a caballeros y freiles siguen un mismo patrón, solo haremos hincapié en éstas cundo sean diversas.

6. ARV, Clero, Montesa, L. 2546. Respecto a los bienes incautados cabe destacar que la Orden nunca obtuvo un beneficio económico real, pues en el registro se observa que las cantidades de entrada y salida son las mismas en todos los casos. Cabe aclarar, para evitar repeticiones, que siempre que nos refiramos a las cantidades no estaremos hablando de ganancias, sino del total del patrimonio secuestrado. 
dentro de esta Orden de caballería. Realmente es un poco difícil valorar el grado de adhesión de sus miembros a una u otra causa, especialmente en lo que se refiere a los caballeros ${ }^{7}$, pero aun así quisiéramos aportar unas pequeñas pinceladas que constituyan el marco contextual sobre el que vamos a movernos a lo largo de estas páginas. En este sentido, el cruzamiento de los testimonios obtenidos por las fuentes documentales juntamente con el trabajo de Cerdà nos lleva a considerar la existencia de unos 43 personajes con probable tendencia filoaustracista dentro de Montesa. De estos, 37 así son caracterizados por dicho autor -entre ellos los procesados-, a los que cabría la posibilidad de sumar 9 individuos más -todos pertenecientes al grupo de religiosos-, gracias a la información derivada de la documentación procesal. Nos encontramos, por tanto, ante 12 caballeros y 25 freiles de los que hemos localizado 9 y 12 procesos respectivamente ${ }^{8}$. De todos ellos hemos analizado su trayectoria tanto en Montesa como al servicio del gobierno austriacista, atendiendo especialmente al papel que desempeñaron durante el conflicto, principalmente el nombramiento y ejercicio de diferentes tipos de cargos, pero también su proceder tras la derrota de Almansa y la represión de la que fueron víctimas.

El grueso de nuestro trabajo se centra en el estudio de los denunciados por la Orden, aunque consideramos que no haber localizado más sumarios no implica que ni solamente ellos fuesen disidentes ni que no existan más procesos ${ }^{9}$. Seguramente forman parte de un grupo mayor, pues existe una premisa fundamental a tener en cuenta: la existencia de casos en que los personajes pudieron mantener una actitud vacilante en cuanto a su posicionamiento político, así como el hecho de que no fueron pocos, en términos generales y no solo dentro de la Orden, los que durante la contienda cambiaron de bando, atendiendo a una gran variedad de circunstancias. Del mismo modo, muchos de los que declararon en el transcurso del juicio trataron de contradecir las acusaciones vertidas sobre ellos, presentándose como fieles partidarios de Felipe V; otros, aunque no negaron su posicionamiento austracista, se mostraron arrepentidos. En este sentido, existen casos en que la disidencia de los inculpados no parece tan fácil de probar e incluso nos podría llevar a considerar que algunos borbónicos también pudieron ser víctimas de la persecución de la

7. No contamos con un listado que especifique la parcialidad de todos los caballeros que formaban parte de la Orden para la cronología, pues Cerdà (2012: I, 468) únicamente trabaja con un muestreo de 34 individuos, intuyendo que la cifra total se situaría alrededor de los 90.

8. Por el momento no hemos hallado procesos sobre los caballeros: José Almunia, Pedro Descallar y José Figuerola; tampoco de los freiles: Jerónimo Alfonso, Antonio Aparicio, Antonio Cruz, Matias Gisbert, Damián Gomar, Tomás Guerola, Pascual Huguet, Francisco Mañes, José Navarro, Montserrat Pareja, Gabriel Segarra, José Soler y Juan José Talens.

9. A modo de ejemplo, existen casos relevantes como el del mallorquín Pedro Descallar, a quien Carlos III le concedió el título de barón de Pinopar, que no fue reconocido por Felipe V; o el religioso Josep Soler que acabó sus días en Viena como capellán del Consejo de Flandes. Unos personajes que necesariamente tuvieron que estar en el punto de mira de la Orden.

Ediciones Universidad de Salamanca / @®@@ Stud. his., H. ${ }^{a}$ mod., 42, n. 2 (2020), pp. 365-400 
disidencia. Por tanto, nos encontramos ante un objeto de estudio que en muchos casos presenta tanto dificultades de interpretación como de localización de información sobre ciertos acusados, lo que nos ha impedido despejar la incógnita sobre su posicionamiento y su trayectoria posterior.

Respecto a los personajes contra los que se iniciaron causas judiciales, nos encontramos frente a un grupo de composición bastante diversa en cuanto a su procedencia social y también a su proyección dentro del gobierno del Archiduque. En este sentido, hemos optado por clasificarlos atendiendo al criterio de sus cargos políticos y militares durante la contienda, ya fuesen caballeros o freiles de Montesa, aunque en cada caso atenderemos a múltiples aspectos de sus vidas y trayectorias.

\subsection{Montesianos en la alta administración del Reino}

Don José Folch de Cardona, conde de Cardona (1651-1729)

Don José de Cardona y Erill nació en 1651 fruto del matrimonio contraído entre don Alonso de Cardona, marqués de Castelnovo, y doña Margarita de Erill, condesa de Erill, su segunda esposa. Su padre murió en 1659 dejando a la familia en unas difíciles circunstancias económicas que los obligó a acudir al favor real en un intento de mejorar su situación. Felipe IV decidió nombrar a la condesa camarera mayor de la emperatriz Margarita de Austria, motivo por el que don José y sus dos hermanas se trasladaron con su madre a la Corte Imperial en 1666. Ya establecido en Viena, nuestro personaje recibió de Leopoldo I varias mercedes y títulos. En 1667 fue nombrado gentilhombre de cámara del Emperador, pasando posteriormente a ostentar el grado de general de caballería y el título de conde de Cardona a partir de $1673^{10}$. Pero, su estancia en Viena finalizó este mismo año por la muerte de la emperatriz y su regreso a la Monarquía Hispánica no aportaba, a priori, esperanzas de continuar en su escalada social. Así las cosas, su madre solicitó licencia a la Monarquía para traspasarle los beneficios de la encomienda de Alcalá de Xivert, perteneciente a la Orden de Montesa, que la condesa gozaba como administradora desde $1657^{11}$. La reina gobernadora autorizó la petición e inmediatamente se iniciaron los trámites para que don José ingresase como caballero de la Orden. Recibió el hábito en 1675 y profesó como caballero tan solo dos años después ${ }^{12}$. En 1677 fue nombrado comendador de Alcalá de Xivert y ese mismo año casó con doña María Manuela Pardo de la Casta, hija del marqués de la Casta ${ }^{13}$. Posteriormente

10. ÖSTA, AVA, Adel RAA, Graf von Cardona, 11/2/1673, ff. 1-8.

11. AHN, OOMM, leg. 3737.

12. AHN, OOMM, L. 560-C, ff. 67r-68r, 113r-114r, 147r, 160r-161v y 163r-165r.

13. Ibid., f. 180r-v. 
el monarca le concedió la dignidad de comendador mayor de San Jorge de Alfama, recuperada a nivel honorifico, y en 1689 fue designado por Carlos II como lugarteniente de Montesa, por fallecimiento de don Juan Crespi ${ }^{14}$. (Pérez, 2002: 426-427; Salas, 2019: 375-378 y 380).

Desde que accedió a la Orden su trayectoria en la misma no puede desligarse de su actuación política. Cabe destacar que en 1679 fue nombrado embajador extraordinario por Carlos II para felicitar a Leopoldo I por el nacimiento de su hijo primogénito, el futuro José I. Una designación que, por un lado, muestra la gran vinculación de Cardona con la Casa Imperial y, por otro, supuso para el personaje una ocasión para endeudarse considerablemente. De hecho, tras mucho rogarlo, en compensación por su dispendio le fue concedida una supervivencia de 14 años en su encomienda. Además, como lugarteniente, el conde se convirtió en la segunda voz del Estamento Eclesiástico, lo que le permitió participar en las instituciones representativas del Reino. Por tanto, desde 1689 lo encontramos asistiendo de forma asidua a las reuniones de las Juntas de Electos de Estamentos, las Juntas de Contrafueros y las Juntas de Costa. Intervenciones al servicio de la Corona y su Reino que incrementaron en 1692 al ser nombrado consejero de Guerra (Salas, 2019: 378-379 y 381).

Pero esta participación en la primera línea de la política valenciana empezó a disminuir considerablemente ante el cambio de dinastía, y es que no en vano se le reconoce como uno de los principales líderes del movimiento austracista valenciano. Y fue gracias a su actuación en este sentido que, tras la proclamación de Carlos III en el Cap $i$ Casal, el mismo Basset lo nombró virrey del Reino, cargo que no quiso comenzar a ejercer hasta recibir el preceptivo privilegio real, expedido en Barcelona en enero de 1706. Don José ejerció un virreinato marcadamente conservador buscando afianzar el apoyo de las clases privilegiadas a la causa imperial. Además, lideró la represión contra los valencianos que abiertamente habían mostrado su fidelidad al Borbón, mediante la confiscación de bienes y las ordenes de destierro. Así mismo, se propuso reactivar el normal funcionamiento de las instituciones valencianas y velar por la buena gestión de las encomiendas de la Orden. Para conseguirlo fue necesario afrontar el vacío de poder existente a consecuencia de la huida de la elite valenciana tras la entrada de Basset en la capital. Y es en este punto en el que se nos permite observar la importancia del personaje por sus contactos, pues consiguió remodelar la composición social de las instituciones disponiendo en los cargos a personalidades de filiación austriacista, entre ellos muchos miembros de la Orden de Montesa. Su virreinato concluyó con la entrada de Carlos III en Valencia a finales de 1706, pero continuó ejerciendo funciones de gran significación política al ser designado miembro de las juntas de Guerra y de Política (Salas, 2019: 384-385).

\section{Ibid., ff. $271 \mathrm{v}$ y $307 \mathrm{v}$.}


El 7 de marzo de 1707 abandonó Valencia junto al Archiduque para establecerse en Barcelona, dada la proximidad de las tropas borbónicas, donde siguió ostentando un papel político preeminente, especialmente al ser nombrado mayordomo mayor de la Archiduquesa Isabel Cristina de Brunswic. Simultáneamente, la Orden de Montesa inició un proceso criminal contra él, acusándolo de infidelidad a Felipe V, conspiración a favor del enemigo y ostentación de una larga lista de cargos para los que había sido designado por el Archiduque. La sentencia en su contra fue publicada el 6 de septiembre de 1707, condenándolo a la perdida de todos los títulos y mercedes recibidos en la $\operatorname{Orden}^{15}$, la retirada del hábito y la confiscación de sus bienes, además de su detención, pues debía ser privado de su libertad. ${ }^{16}$ La suma de los bienes confiscados entre 1707 y 1725 supuso una ganancia de poco más de 4.300 libras para la Orden, la mayor parte de las cuales derivaban de una pensión que el conde tenía asignada sobre la mitra de Mallorca, pues no contaba con posesiones inmuebles en el reino ${ }^{17}$ (Pérez, 2002: 438-442; Salas, 2019: 385-387).

Con todo, la perdida de las dignidades y rentas montesianas no significó un descenso en la posición del conde, ya que Carlos III supo compensar sus esfuerzos y fidelidad. Durante su estancia en Barcelona fue nombrado consejero de Estado y Guerra y miembro del Real Gabinete, además de concederle en 1709 la Grandeza de España ${ }^{18}$ y, más tarde, el Toisón de Oro en agradecimiento por su actividad en el gobierno durante el periodo de regencia de la Archiduquesa. En 1713 se exilió a Viena junto a la ya Emperatriz y allí continuó su escalada de honores. En 1715 le fue otorgada la nacionalidad húngara, posibilitando así una futura conversión en señor de vasallos. Este salto tardó poco en hacerse realidad, pues el Emperador Carlos VI le concedió en propiedad el distrito y ciudad de Virovitica (Eslavonia). Dos años después fue designado presidente del recién creado Consejo de Flandes y en 1722 le fue concedida la máxima dignidad imperial, el título de Príncipe del Imperio. Una escalada de honores que fue acompañada de una mejora exponencial de su situación económica, debido a que el Emperador le concedió un sueldo anual de 10.000 florines. (Pérez y Felipo, 1998: 333-334; Salas, 2019: 387-389). Además, también pudo beneficiarse de las ayudas concedidas por el Bolsillo Secreto de Carlos VI, llegando a ingresar un total de 13.225 florines, a cuenta de diferentes conceptos, entre 1719-1728 (León, 1998: 588 y 594-595). Evidentemente apoyar a la causa imperial

15. Esto suponía la perdida de la dignidad de comendador de Alcalá de Xibert y San Jorge de Alfama, juntamente con el derecho de cobrar las rentas de ellas derivadas, y evidentemente fue cesado como lugarteniente. Pero estas rentas no se incluyeron entre los bienes secuestrados, dado que Felipe $\mathrm{V}$ premió la fidelidad del conde del Real designándolo como poseedor de las dos encomiendas. Ver AHN, OOMM, leg. 3737 y ARV, Clero, Montesa, c. 2340-41.

16. ARV, Clero, Montesa, c. 2424-25, exp. 13.

17. ARV, Clero, L. 2546.

18. ÖSTA, AVA, Adel RAA, Folch von Cardona von Erill, 1/12/1722, ff. 1-14. 
fue altamente beneficioso para don José, y más si a todos los honores conseguidos en el exilio sumamos la recuperación de los bienes y dignidades montesianas tras la firma del Tratado de Viena en 1725, a excepción de la lugartenencia.

Frey Antonio de Benavides y Fenollet (1661-1716)

Freile montesiano, había nacido en Valencia fruto del matrimonio entre Eusebio Benavides, notario y escrivà de manament de la Real Audiencia Valenciana, y Estefanía Fenollet. Entró en la Orden en 1678 y en ella inició sus estudios, llegando a conseguir el grado de licenciado y a ostentar posteriormente la cátedra de Teología Moral. Además, disfrutó de la condición de beneficiado de las almas en la capilla de la Coronación de Nuestra Señora, situada en el convento de Montesa (Cerdà, 2012: III,40). La participación de Frey A. Benavides al servicio de la causa austracista se muestra especialmente en su ocupación como secretario del virrey Cardona, labor que ostentaba con anterioridad, al ayudar al noble en sus quehaceres relacionados con la lugartenencia de la Orden (Cerdà, 2012: III, 40; Pérez, 2009: 413). Además, antes de que su virreinato finalizase -por la inminente llegada del monarca a Valencia- el conde decidió situarlo al frente de la encomienda de Culla. Esta había quedado sin administrador porque su comendador, don Luis Ignacio de Borja y Fernández de Córdoba, marqués de Llombai, se había refugiado en tierras castellanas por su posicionamiento borbónico ${ }^{19}$. Por tanto, el virrey estaba cubriendo una plaza vacante a la vez que represaliaba a un personaje claramente posicionado en el bando opuesto. Tras la llegada de Carlos III a la ciudad del Turia, el monarca se propuso reestructurar la composición de las instituciones del reino para asegurarse la fidelidad de aquellas personas que ostentaban el poder político. Así, el 27 de diciembre de 1706 inició la reorganización de los oficios de la Generalitat, entre ellos el puesto de síndico. La elección no estuvo libre de controversias, pues no se consiguió realizar un nombramiento por unanimidad y los asistentes acabaron por realizar un sorteo, el resultado del cual fue la designación de Frey Benavides como síndico de la institución para el trienio 1707-1709 (Pérez, 2009: 539-540; Villamarín, 2016: 52).

Dado este historial de servicios a la causa imperial, en mayo de 1708 la Orden inició el proceso judicial pertinente. En él se constata su papel como secretario del virrey, destacando que rubricaba los despachos de la secretaría y que vivía con el conde en el mismo palacio del Temple. Además, atestiguaban su participación en el encarcelamiento de los borbónicos que se habían mantenido en Valencia, cargos a los que sumaban el ejercicio de los oficios que acabamos de comentar y el refugio en Barcelona junto a otros valencianos tras la derrota en Almansa, donde siguió su

19. ARV, Clero, Montesa, c. 2424-25, exp. 31.

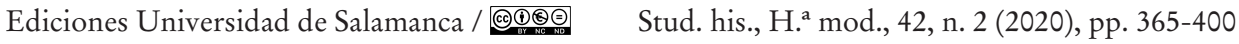


trato cotidiano con don José Folch de Cardona ${ }^{20}$. Sin embargo, nos hallamos ante uno de los procesos que se encuentran inconclusos. Según atestigua Cerdà (2012: III, 41), el freile se encontraba en las cárceles de la Orden en 1714, lo que nos lleva a considerar que fue apresado tras la caída de Barcelona y murió en 1716, probablemente en la prisión y antes de que el tribunal publicase la sentencia en su contra.

\section{Don Gaspar de Calatayud, Vilarig y Carròs, conde de Cirat (1640-1717)}

Don Gaspar fue hijo de don José de Calatayud, señor de Agres, y doña Damiata Carròs, hija y heredera del conde de Cirat. Formaba parte, por tanto, de una de las principales familias de la nobleza valenciana, contando entre sus ascendientes a personajes de importancia entre la sociedad política del reino, especialmente por la usual ostentación del cargo de baile entre los Carròs. Gracias al honor de su casa le fue concedido el hábito de Montesa en 1670 y tiempo después fue designado para el ejercicio de diversos oficios de carácter militar dentro de la Orden, siendo nombrado «acompañante» del comendador de Silla en 1692 y posteriormente del de Ademuz en 1696, para pasar a ostentar el cargo de lugarteniente y capitán general de la bailía de Moncada en 1702; para todos los cuales fue nombrado en tiempos del lugarteniente Cardona (Cerdà, 2012: II, 108).

La vinculación de don Gaspar con la causa imperial puede tratar de entenderse desde diferentes puntos de vista. Por un lado, el parentesco con otras de las principales familias que se posicionaron a favor de Carlos III, especialmente los condes de Villafranqueza, con los que se había llevado a cabo unos años antes una doble política matrimonial. Don Gaspar había casado hacia 1690 con doña M. ${ }^{a}$ Teresa Siverio, hermana del conde de Villafranqueza, mientras que este contrajo matrimonio con doña Damiata Calatayud, hermana del de Cirat. Además, mediante este enlace también emparentaban con el conde de Cardona, dado que Teresa y José eran hijos de su sobrina Ana M. ${ }^{a}$ Folch de Cardona (Chiquillo, 1991: 139)21. Unos vínculos familiares que debemos tener en cuenta para para explicar la proyección del personaje y su trayectoria al servicio del Archiduque. Por otro lado, gran parte de la actividad económica de los de Cirat se centraba en la inversión comercial ligada a compañías holandesas e inglesas, por lo que la política mercantil borbónica dañaba sus intereses financieros, lo que pudo ser determinante en su posicionamiento (López, 2015: 293).

Con todo, el aspecto que más nos interesa destacar del personaje es el acrecentamiento de su proyección política a lo largo del conflicto sucesorio. Concretamente en 1706 fue nombrado maestre racional del Reino de Valencia por el virrey Cardona.

20. Idem.

21. Ana M. ${ }^{a}$ Folch de Cardona, era hija de don Antonio de Cardona, marqués de Castelnovo. Este, a su vez, era hermanastro, por parte de padre, del conde de Cardona. 
Además, fue uno de los siete nobles ${ }^{22}$ que el 1 de julio de 1706 viajaron a Tortosa para rendir pleitesía a Carlos III y acompañarlo en su intención de viajar hacia Valencia. La travesía no se realizó según lo planeado, pues el Archiduque decidió acudir en primer lugar a Aragón, acompañado, entre otros, por los valencianos conde de Cirat y don Galcerán Mercader, quienes asistieron al juramento de los Fueros aragoneses en Zaragoza. Así mismo, la proximidad y fidelidad a Carlos III pudieron ser la motivación para que en diciembre de 1706 fuese nombrado por el monarca baile general de Valencia, cargo que juró hacia el 20 de enero de $1707^{23}$ y que ostentó hasta marzo de ese año, cuando abandonó tierras valencianas para asentarse en Barcelona, siguiendo al Archiduque ante la inminente victoria borbónica (Pérez, 2009: II, 418, 507-508 y 571). En el Principado continuó muy vinculado a la causa austracista, mientras que en Valencia en 1708 la Orden de Montesa abrió una causa criminal en su contra, acusándolo de infidelidad al monarca por aceptar, jurar y ostentar de mano de los enemigos el cargo de baile, así como seguirlos en su exilio a Barcelona. Además, una deslealtad agravada al haber jurado en nombre de Felipe V -como administrador perpetuo de la Orden- su cargo como bailío de Moncada, Carpesa y Borbotó en enero de 1703, lo cual suponía haberlo reconocido como rey para posteriormente prestar fidelidad al otro pretendiente, cometiendo un delito de rebelión. Con todo, la sentencia fue publicada el 4 de septiembre de 1708 , siendo condenado a las sanciones acostumbradas ${ }^{24}$. La confiscación de los bienes se materializó en base a sus posesiones inmuebles, concretamente tres casas situadas en la ciudad de Valencia y las rentas señoriales de sus baronías. Del arrendamiento de las tres viviendas entre 1708 y 1725 -año en que recuperó sus bienes consecuencia de la Paz de Viena- la Orden obtuvo un poco más de 2.200 libras, mientas que de sus posesiones en Agres, Cirat, Pandiel, Tormos y Sella reunieron poco más de 41.100 libras, por lo que la entrada total supuso aproximadamente unas 43.300 libras, prácticamente la misma cantidad que la Orden calculó de salidas, dado que el patrimonio del conde de Cirat respondía una gran cantidad de censos que comprometían la práctica totalidad de sus ingresos ${ }^{25}$.

Finalmente, don Gaspar murió exiliado en Milán hacia $1717^{26}$. Ciertamente poco se conoce sobre su trayectoria en el norte de Italia, aunque es importante

22. Estos fueron: Don Juan Pardo de la Casta y Palafox, marqués de la Casta; don José Severio Folch de Cardona, conde de Villafranqueza; don Antonio Tomás Cabanilles, conde de Casal; Don Juan Antonio Boixados de Pinós, conde de Savallá; don Galcerán Mercader y Cernesio, don José Sans de Xeta y el conde de Cirat.

23. ARV, Clero, Montesa, c. 2424-25, exp. 12.

24. Ibid, exp. 20.

25. ARV, Clero, L. 2546.

26. Parece ser que su esposa no abandonó nunca tierras hispánicas, lo cual explica que poco después de la firma de la Paz de Viena se encuentre gestionando aspectos relacionados

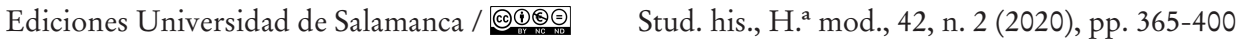


apuntar que su temprana muerte le impidió disfrutar de las posibles mercedes con las que Carlos VI pudo haber premiado sus esfuerzos. Aun así, el emperador no se olvidó de la casa de Cirat, por lo que su primogénito, don Bernardo, heredó el título nobiliario y continuó al servicio militar del Imperio, desarrollando gran parte de su carrera tanto en la Corte vienesa como en Hungría. Cabe destacar que fue nombrado capitán en Hungría y gentilhombre de cámara del Emperador. Parece que consiguió volver a dominios hispánicos, donde se encontraba hacia 1750, también como heredero del condado de Villafranqueza, según el testamento de su tío, don José Siverio. Otro de sus hijos, don Ignacio, estuvo exiliado en Sicilia, aunque no sabemos si consiguió retornar (León,2014: 218 y 222; Pérez y Felipo, 1998: 335).

\section{Don José Sans de Xeta (1667-¿?)}

Personaje nacido en la ciudad de Valencia, hijo de Juan Bautista Sans de Xeta y María Enríquez de Montalvo, ingresó como caballero de Montesa en 1686, aunque no ejerció ningún oficio o dignidad en la Orden (Cerdà, 2012: II, 679-680). Su actividad vinculada con el gobierno austriaco se dio en el ámbito militar y político. Por un lado, colaboró con las tropas aliadas en los hechos de armas castellanos; por otro, ejerció el oficio de teniente de maestre racional de Valencia por designación del virrey Cardona, cargo en el que fue reafirmado por el Archiduque ${ }^{27}$. Además, don José fue uno de los nobles valencianos que el verano de 1706 viajó a Tortosa con el objetivo de mostrar pleitesía al Archiduque y acompañarlo en su viaje a Valencia. El viaje se pospuso, pero su participación muestra su posición como uno de los principales austriacistas valencianos y su compromiso con la causa ${ }^{28}$.

Contra Sans de Xeta también se abrió un proceso criminal, por el que el 28 de agosto de 1708 se publicó el laudo en su contra. La acusación de infidelidad y colaboración con el enemigo de la Corona se centraba en la actuación que llevó a cabo en ayuda del pretendiente austriaco, agravada, además, por su huida a Barcelona tras la batalla de Almansa. En consecuencia, sufrió la misma condena que sus correligionarios $^{29}$. En relación con la incautación cabe destacar que únicamente se realizó sobre bienes muebles, por lo que las 358 libras y 12 sueldos que consiguió reunir la

con el retorno de los bienes del Conde de Villafranqueza. ÖSTA, HHStA, StAbt, Spanien Varia, k. 39-5-7, ff. 11r-12v.

27. En el proceso por austracismo solo queda constancia de su nombramiento como teniente del maestre racional por parte de Carlos III, cargó que don José juró el 6 de febrero de 1707. Pero, según constata Pérez (2009: II, 418), el virrey Cardona ya lo había nombrado en 1706 para ostentar dicho oficio de forma interina, hasta esperar la designación oficial por parte del monarca.

28. ARV, Clero, Montesa, c. 2426, exp. 7.

29. Ídem. 
Orden fueron fruto del depósito para el retorno de los mismos entre 1708-1715 ${ }^{30}$. Acabado el conflicto en tierras hispánicas sabemos que don José se exilió a Viena, donde en 1715 comenzó a cobrar una pensión en Nápoles (Alcoberro, 2002: II, 52; López, 2015: 500). Por otro lado, en 1716 presentó un memorial al Consejo de España para recordar la existencia de un crédito de 5.000 libras valencianas que le adeudaba la Real Hacienda. El interesado tenía depositada esta cantidad en la Taula de Canvis de Valencia, procedente del secuestro de los bienes del duque de Medinaceli, Dénia y Segorbe, en paga de la deuda que dicho duque había contraído tiempo atrás con Sans. Dicho dinero había sido extraído de la Taula en 1707 para ayudar a Carlos III en sus necesidades económicas y aún no le había sido restituido en su totalidad, por lo que pedía que la parte adeudada le fuese satisfecha del producto de las Salinas de Cardona ${ }^{31}$. A partir de aquí ya no hemos reunido más noticias de la trayectoria del personaje hasta el momento de su muerte.

\section{Frey Fernando Menor y Fenollet (¿?- ca.1707)}

Natural de Játiva, hijo de José Menor y Casilda Fenollet, ingresó en Montesa en 1694. Tras su profesión inició estudios académicos que le valieron el título de licenciado, aunque no conocemos en qué especialidad (Cerdà, 2012: III,186-187). En 1703 fue designado por Felipe V rector de la villa de Vinaroz, cargo al que renunció al ser nombrado por el virrey y lugarteniente Cardona como asesor del baile general de Valencia el 27 de febrero de 1706 y que juró al día siguiente. ${ }^{32}$ Frey F. Menor ejerció el oficio hasta que se exilió a Barcelona tras la derrota de las fuerzas aliadas en Almansa y allí continuó en contacto con el resto de extrañados valencianos, especialmente con el Conde de Cardona, tal y como afirman los testigos del proceso. Como es de esperar la Orden lo juzgó por traición y colaboración con el enemigo, basándose en el desempeño de las funciones de su puesto en la Bailía y la posterior fuga al Principado. El proceso comenzó en junio de 1708, aunque se encuentra inconcluso ${ }^{33}$, creemos que como consecuencia de la temprana muerte del freile, de forma que se paralizaría cuando la Orden tuvo noticia de su muerte.

30. ARV, Clero, L. 2546.

31. ÖSTA, HHStA, Italien-Spanischer Rat, Supremo Consejo de España, k. 13, ff. $252 \mathrm{r}-254 \mathrm{v}$. Seguramente la merced nunca fue efectiva, pues el Emperador no volvió a ostentar autoridad en Cataluña.

32. Asistieron como testigos al juramento del cargo el caballerizo José Lloris y Francisco Gutiérrez, teniente capitán de la guardia del virrey. Cabe destacar que, en el proceso judicial, como prueba de que ejerció dicho oficio, se presentan las cartas de pago de su salario, gracias a las cuales hemos podido conocer que ostentar dicha asesoría suponía un ingreso anual de 500 libras.

33. ARV, Clero, Montesa, c. 2424-25. Según apunta Cerdà (2012: II, 186), el fraile debió morir hacia 1706. Nosotros consideramos que fue como pronto en 1707 , sino no hubiese tenido tiempo de huir a la Ciudad Condal tras el suceso de Almansa.

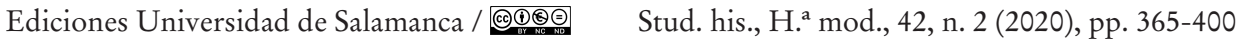


Don Luis Pasqual y Canísia (1658-ca. 1725)

Nacido en Alicante, hijo de Juan Pascual y Ana Canícia, ingresó en Montesa en agosto de 1684 y profesó dos años más tarde. Ya en el último periodo del reinado de Carlos II ejercía el oficio de sargento mayor de las milicias de Alicante, empleo que continuaba sirviendo en 1705 (Cerdà, 2012: II, 571; López, 2015: 486). Su actividad filoaustracista inició el verano de 1706, en el contexto en que Peterborough, aprovechando la debilidad del ejército borbónico tras el fracaso del sitio barcelonés, se propuso conseguir la rendición de Alicante. Evidentemente era una plaza importante para los aliados, al considerar la importancia estratégica de su puerto y entenderla como la puerta de entrada a Castilla (Pérez, 2009: II, 457-461). Días antes de que se produjese el ataque, don Luis dejó la ciudad y se estableció en Villajoyosa, ya bajo domino austracista. El asedio comenzó el 2 de agosto y el día 8 las tropas aliadas entraron en la ciudad, entre ellas don Luis como capitán de un contingente de paisanos y miqueletes. Como recompensa a su participación, fue designado baile general de Alicante, oficio que sirvió hasta el momento de la recuperación borbónica de la ciudad en noviembre de 1709. Gracias a la ostentación del cargo, vehiculó la represión sobre la población filoborbónica, arguyendo que contaba con comisión para perseguir, encarcelar y multar a los botiflers. De hecho, muchos fueron privados de su libertad $\mathrm{u}$ obligados a abandonar la ciudad $\mathrm{y}$, con ello, sus casas y haciendas. Restablecida la obediencia al Borbón, don Luis y su familia consiguieron asentarse en territorio catalán, escapando así de la represión, aunque en 1713 decidió presentarse voluntariamente en el convento de Montesa y la Orden lo puso bajo arresto ${ }^{34}$.

Los testimonios, en sus declaraciones de septiembre de 1709, confirmaban la trayectoria austriacista seguida por el personaje, aunque la acusación formal no tuvo lugar hasta junio de 1716. El imputado admitía haber ejercido como baile interino, aunque presionado por los austracistas, quienes le amenazaron con derribar unas casas de la ciudad que eran de su propiedad ${ }^{35}$. Del mismo modo, negaba haber perseguido a los vasallos borbónicos, pues defendía que las diferentes medidas aplicadas eran inherentes al ejercicio del oficio que desempeñaba. En nuestra opinión este argumento carece de sentido, sobre todo si valoramos la lógica seguida por el gobierno austriacista a la hora de designar a aquellos que debían situarse al frente de las principales instituciones regnícolas, ya que siempre escogieron individuos de fidelidad probada. La Bailía alicantina era importantísima para la gestión del Real Patrimonio, en tanto en cuanto el puerto de la ciudad era uno de los más importantes del Reino, entre otros muchos aspectos; por lo que parece improbable que no siguie-

34. ARV, Clero, Montesa, c. 2507-08, no 21.

35. Idem.

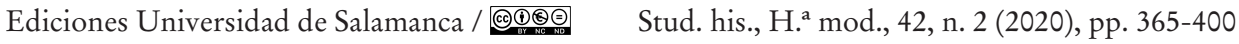


ran el mismo patrón a la hora realizar el nombramiento. Por tanto, consideramos que el personaje sí estuvo estrechamente vinculado con la causa imperial, aunque quizá no contase con una solvencia económica que le permitiese exiliarse. Finalmente, decidió presentarse arrepentido ante la Orden e implorar misericordia, en un intento de escapar de la represión, o reducirla a su mínima expresión. Aun así, decidieron encarcelarlo ${ }^{36}$, aunque la acusación del promotor fiscal no se realizó hasta 1716. En ese momento, tras años de prisión, don Luis consideraba que ya había cumplido con el castigo o, al menos, con gran parte del mismo, por lo que apelaba a la benignidad del monarca y solicitaba ser puesto en libertad; opinión que no compartía el fiscal. Con todo, el proceso resta inacabado, aunque suponemos que sí existió una sentencia en su contra ${ }^{37}$, ya que en el libro de secuestros aparece una entrada de sus bienes entre 1722-1727, por los que la Orden obtuvo un recaudo de 301 libras 3 sueldos y 4 dineros, aunque no se especifica claramente de donde provienen dichas cantidades ${ }^{38}$. El personaje falleció a finales de la década de 1720 en una situación de extrema pobreza, lo que obligó a la Orden a hacerse cargo de los gastos del sepelio (Cerdà, 2012: II,572), argumento que apoya nuestra tesis sobre la imposibilidad del exilio.

\section{Don Isidoro Vaillo de Llanos (1688-1732)}

Natural de Elche, hijo de José Vaillo de Llanos y Cresencia Ortiz de Malla, era miembro de una de las familias pertenecientes a la oligarquía urbana que había conseguido enriquecerse gracias a la concentración de posesiones agrarias. Ingresó como caballero de Montesa en 1697, pero parece ser que no ostentó ninguna dignidad dentro de la Orden hasta que -ca. 1707- el Archiduque lo nombró comendador de Ares. En el marco de conflicto sucesorio, su actuación tuvo especial relevancia en la decisión de su localidad natal de reconocer como su legítimo rey a Carlos III. De hecho, cuando en julio de 1706 el ejército aliado se encontraba cerca de la ciudad, gran parte de los miembros del consejo municipal decidieron prestar obediencia, entre ellos nuestro personaje (Cerdà, 2012: II, 790; López, 2015: 294 y 431; Pérez, 2009: II, 534 y 545). Su inclinación por la causa austracista lo llevó a asentarse, junto a su familia, en la capital del Reino. Durante el período participó en diversos actos públicos y manifestaciones de alegría por las victorias aliadas, al mismo tiempo que

36. Don Luis pasó 14 meses en las prisiones del convento de Montesa, seguidamente fue trasladado al castillo de la Orden, donde estuvo 2 años y 10 meses, y finalmente fue llevado a la Torre del Temple, lugar en el que llevaba 3 meses.

37. Cerdà (2012: II, 572) constata que en junio de 1712 Felipe V autorizó la publicación de una sentencia en su contra. Creemos que el caballero se presentó ante la Orden antes de la lectura de la misma, lo cual explicaría la reanudación del proceso en 1716.

38. ARV, Clero, 1. 2546. 
estableció proximidad con el gobierno austracista y su monarca, probablemente en busca de mercedes. Finalmente, su labor fue recompensada con el nombramiento de teniente de gobernador de Alicante de manos del marqués de Rafal, al que el mismo Carlos III había designado gobernador de Orihuela ${ }^{39}$.

Repitiendo el patrón seguido por la gran mayoría de los caballeros de Montesa con filiación austracista, Vaillo también se estableció en la capital del Principado tras la derrota de Almansa, donde continuó obteniendo mercedes de parte de Carlos III, quien en el contexto de su enlace con Isabel Cristina de Brunswic lo designó lugarteniente de gobernador de Orihuela (Feliu, 1709: 598). Aunque, lógicamente, su austracismo lo llevó a ser juzgado por el tribunal montesiano, pues en 1709 ya habían comenzado a recabar información sobre su participación en el gobierno, incluso llegaron a registrar su casa en busca de correspondencia, seguramente con intención de obtener pruebas fehacientes para inculparlo, así como nombres de sospechosos y conocer posibles estrategias aliadas. Aun así, no queda reflejado en la documentación si realmente consiguieron encontrar algún escrito. La sentencia en su contra se publicó el 9 de septiembre de ese mismo año, atendiendo a los cargos de colaboración con el enemigo por ejercer el oficio de teniente de gobernador de Alicante, una cooperación que mantenía al seguir al Archiduque a tierras catalanas. Así las cosas, la condena impuesta fue la misma que a la mayor parte de los caballeros ${ }^{40}$. Fruto del secuestro de sus bienes la Orden reunió un total de 660 libras entre 1710-1716, aunque no se explicita su procedencia en el libro de cuentas ${ }^{41}$. A esta dificultad debemos sumar el hecho de que el 12 de septiembre de 1716 la Orden concedió a la esposa de don Isidoro, doña María Ferrer y Pedrón, una paga anual de 500 libras en concepto de alimentos, destinada a su propia manutención y la de sus hijos, cantidad que debía abonarse de los bienes secuestrados ${ }^{42}$. De hecho, lo más probable es que la Orden acabase devolviendo a la familia los bienes, dado que la cantidad consignada en alimentos era mucho más alta que el total recaudado en varios años. Esto puede explicar que solo haya registro de la incautación hasta 1716, pues parece difícil pensar que la Orden se hiciese cargo de abonar 500 libras anuales a la familia de un «traidor».

Por último, cabe destacar que, tras la caída de Barcelona bajo dominación borbónica en 1714, don Isidoro se exilió a Génova donde se estableció por un tiempo hasta acabar asentándose en Viena; lugar en el que testó y falleció en 1732 disfrutando de la dignidad de marqués de Villamar y de gentilhombre de cámara del emperador, por gracia y merced Carlos VI en recompensa a su fidelidad y servicios. Realmente poco

39. ARV, Clero, Montesa, c. 2426, exp.14.

40. Ídem.

41. ARV, Clero, L. 2546.

42. ARV, Clero, Montesa, c. 2424-25, exp. 30.

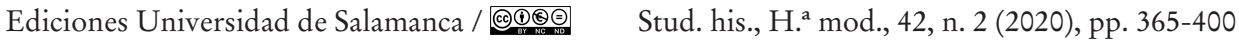


conocemos de sus años en el exilio, aunque presuponemos que dada su posición y el goce de una renta consignada sobre Nápoles desde 1715 (Alcoberro, 2002; II,51) su extrañamiento no debió suponer una experiencia traumática para el personaje. Además, mantuvo una estrecha relación con otros relevantes austracistas exiliados en la capital imperial, como el conde de Montesanto, el marqués de Rialp, el conde de Villafranqueza y el marqués de Boïl, a quienes nombró sus albaceas ${ }^{43}$.

\section{Don Galceran Mercader y Cernesio (1665- ¿ ?)}

Caballero de Montesa, nació en la ciudad de Valencia fruto del matrimonio de don Jerónimo Mercader y doña María Cernesio, miembros de dos importantes linajes nobiliarios del reino. Ingresó en la Orden en 1690, aunque no fue un caballero con especial relevancia en la misma (Cerdà, 2012: II, 479). En cambio, sí es digna de mención su actividad al servicio del Archiduque, particularmente en el mundo de la diplomacia y la política. En primer lugar, cabe destacar que formó parte de la comitiva que en julio de 1706 salió del puerto de Valencia rumbo a Cataluña con el objetivo de presentarse ante el Archiduque para mostrarle su fidelidad y acompañarlo en su viaje hacia Valencia. Como vimos anteriormente la travesía se pospuso, pero don Galcerán y el conde de Cirat acompañaron a Carlos III a Aragón y presenciaron el juramento de los Fueros. Por tanto, su presencia en ambos actos nos muestra una clara unión con la causa aliada. (Pérez, 2009: II, 507-508). Esta vinculación estuvo recompensada por el monarca, al nombrarlo comendador de la villa de Onda, perteneciente al borbónico duque de Gandía (Chiquillo,1991:126). Además, es posible constatar la proximidad del personaje con el lugarteniente general de la Orden, ya que el 25 de diciembre 1706 fue escogido como diputado eclesiástico para el trienio 1707-1709, pero desde un primer momento delegó dichas funciones en manos de don Galcerán (Pérez, 2009: II, 538). De hecho, la escritura de representación fue realizada el 31 de diciembre y a partir del día siguiente Mercader tomó posesión del cargo y asistió asiduamente a las reuniones de la Generalitat ${ }^{44}$. Por otro lado, el lugarteniente general lo nombró el 15 de marzo de 1707 procurador general de Montesa, ocupación ejercida hasta el momento por don Guillermo Pertusa y Brizuela, pero que había quedado vacante. El agraciado juró el cargo al día siguiente y lo ejerció hasta que se ausentó del reino tras el suceso de Almansa. $\mathrm{Su}$ extrañamiento de tierras valencianas fue bastante distinto al de otros austracistas, ya que pasó al reino de Aragón donde se mantuvo hasta noviembre de 1708 en qué consiguió llegar a Barcelona tras viajar de paisano y sufrir diversas penalidades, como él mismo atestigua:

43. ÖSTA, HHStA, HA OMaA, k.633-67, s. f.

44. ARV, Clero, Montesa, c. 2424-25, exp. 7.

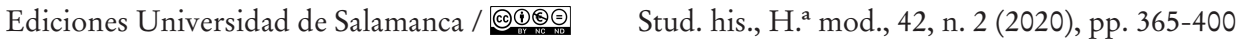


perseguido de forma que, vestido de villano por los montes, con mucho trabajo y con notorios peligros, se mantuvo desde que las armas enemigas entraron en aquel reyno, hasta que pudo lograr ocasión de ponerse a los reales pies de Vuestra Magestad $^{45}$.

Asentado en el Principado, presentó un memorial al Consejo de Aragón pidiendo que el monarca le concediese la administración del secuestro de los bienes del condado de Buñol, por el cual existía un pleito pendiente. Declaraba ser el único pretendiente que había reconocido a Carlos III, consecuencia de lo cual todos sus bienes habían sido incautados, por lo que no contaba con medios para mantenerse. El 17 de abril de 1709 el rey aprobó la petición, incluida la condición de poder administrar los bienes sin tener que dar cuenta a la Real Hacienda ${ }^{46}$; aunque esta merced no debió hacerse efectiva nunca, pues los austracistas no recuperarían el control sobre el territorio valenciano. Por otro lado, cabe destacar que en 1708 Mercader ostentaba la dignidad de gentilhombre de la Real Cámara, además de haber sido nombrado consejero de hacienda (Feliu, 1709: 629). Paralelamente se abrió en su contra un proceso judicial. La sentencia fue publicada el 9 de diciembre de 1709. En ella fue condenado a las habituales penas de incautación, perdida del hábito, prisión y satisfacción de los costes del juicio ${ }^{47}$. En relación con sus bienes, sufrió el secuestro de dos casas situadas en Valencia, concretamente en la parroquia de San Andrés, pero solo aquella que había sido la vivienda de don Galcerán supuso un aporte económico para la Orden. Por su arrendamiento, cifrado en 24 libras anuales, consiguieron reunir un total de 362 libras 18 sueldos entre 1710-1725. La otra vivienda pertenecía a su hermano, también austracista, don Francisco Mercader. Este domicilio no fue arrendado -aunque fue tasado con un valor mucho más alto, 120 libras anuales- porque se encontraba en mal estado y precisaba de obras. Así las cosas, en 1724 los de Montesa llegaron a un acuerdo con el gobernador don Juan Esteban Vellet, quien se comprometió a realizar los trabajos necesarios para su remodelación a cambio de no pagar ninguna renta, de forma que fijó en dicho lugar su residencia ${ }^{48}$.

Por último, destacar que don Galcerán acabó exiliándose a dominios imperiales, donde sabemos se encontraba en 1714, según el listado elaborado en Viena en el que se encuentra clasificado como noble de segunda clase, lo cual comportaba el cobro de una pensión anual de entre 1.000-4.000 ducados (Alcoberro,2002:II, 28; León, 1991:167), aunque no hemos podido localizar más información sobre la trayectoria posterior del personaje.

45. ÖSTA, HHStA, StAbt, Spanien Varia, k. 48-4, ff. 733r.

46. Idem, ff. $733 \mathrm{r}-737 \mathrm{v}$.

47. ARV, Clero, Montesa, c. 2424-25, exp. 7.

48. ARV, Clero, L. 2546. 
MARIA SALAS BENEDITO

INFIDELIDAD Y PUNICIÓN. CABALLEROS Y FREILES AUSTRACISTAS

ANTE EL TRIBUNAL DE LA LUGARTENENCIA GENERAL DE MONTESA

\subsection{Los gobernadores militares y otros cargos del ejército}

Don Fabian Cerdà y Olomar (1670-1721)

Natural de Xàtiva, Sebastián Fabián Cerdà y Olomar fue hijo de José Cerdà e Inés Olomar, ambos naturales de dicha villa. Ingresó en la Orden de Montesa en 1700 ya casado con Jesualda Sans de Llosa (Cerdà, 2012: II, 176-177). Su filiación a la causa del Archiduque se constata ya en tiempos del virrey Cardona, cuando este lo nombró en julio de 1706 como comisario de los secuestros de bienes que debían llevarse a cabo sobre cuatro miembros de la Orden afincados en Onteniente: don Diego Sans de Vallés, don Dionisio Ríos, don José Montoro y Ferrer y don Jerónimo Sancho. Una designación que evidentemente muestra la confianza del lugarteniente y virrey en su persona, al encargarle los secuestros y la realización del perceptivo inventario ante notario. Poco tiempo después, en el contexto de la entrada de Carlos III en Valencia, don Fabián fue elegido embajador de su ciudad natal para cumplimentar al monarca, ocasión que indudablemente le ofreció la oportunidad de estrechar lazos con su proyecto político ${ }^{49}$.

Su labor y fidelidad fue recompensada en marzo de 1707. El día 9 juró ante el lugarteniente como gobernador de la Universidad de Sueca ${ }^{50}$-cargo que debía suponerle una ganancia económica de 600 libras anuales-, mientras que dos días después aceptó ser diputado por el brazo militar como delegado del conde de Cardona, quien había sido elegido para el cargo en el trienio 1707-170951 (Pérez, 2009: II, 545). Tras la batalla de Almansa y la rendición de la capital, nuestro personaje permaneció en la ciudad de Xàtiva, desde donde pidió ayuda militar al conde de Cardona y a Peterborough para poder hacer frente al asedio borbónico sufrido en mayo de 1707. Cerdà obtuvo algunas ayudas, aunque insuficientes, ya que Felipe $V$ recuperó el dominio sobre Xàtiva tras abrasarla y don Fabian optó por exiliarse a Barcelona. Establecido en el Principado, Carlos III decidió nombrar al montesiano Luis Mayans como gobernador de Sueca, para cubrir la vacante dejada por Cerdà, pero este no quiso renunciar al sueldo como gobernador y reclamó al monarca que le fuese devuelto el cargo, que finalmente consiguió. Además, sus servicios fueron recompensados con el título de marqués de Cerdán y la promesa de la concesión de una renta o baronía en Nápoles. La merced fue concedida por Carlos VI en diciembre de 1712 pero en su vertiente crematística aún no se había hecho efectiva en marzo de 1713,

49. ARV, Clero, Montesa, c. 2424-25, exp. 2 y 10.

50. Fueron testigos a este juramento dos miembros de Montesa de claro posicionamiento austracista, don Carlos Berenguer y don José Almunia.

51. Inicialmente el conde había delegado en la persona de Galcerán Mercader, quien a su vez comisionó en don Fabian Cerdà. 
motivo por el cual el interesado presentó un memorial al Consejo de Aragón. La emperatriz la confirmó, pero no sabemos si Cerdà acabó disfrutando de la gracia ${ }^{52}$.

Tras su marcha a dominios austracistas la Orden de caballería inició el perceptivo proceso judicial, acusándolo de traición al monarca y de ayuda al enemigo, centrándose sobre todo en los diferentes cargos que había ostentado por designación del conde de Cardona y del Archiduque, así como en su huida al Principado. El resultado fue la lectura de su sentencia el 27 de abril de 1709 mediante la que fue condenado a las mismas penas que sus correligionarios. Respecto a los bienes incautados nos encontramos frente a un caso un tanto dudoso. En el libro de cuentas de la Orden no aparece ninguna entrada relativa a los bienes de don Fabián, aunque sí existe una petición de retorno de la dote por parte de su esposa, doña Jesualda Sanz, aprobada en mayo de 1708. La interesada reclamaba la restitución de 9.000 libras, con anterioridad a la publicación de la sentencia en contra de su marido, por lo que probablemente el secuestro no llegó a efectuarse en un primer momento. Con todo, el edicto de destierro promulgado por Felipe $V$ obligó a doña Jesualda a abandonar tierras valencianas y en consecuencia los bienes fueron incautados. En 1714 , cuando pudo retornar, inició un nuevo proceso judicial alegando que el fisco aun le debía 4.968 libras del total de su dote, motivo por el que pidió que los bienes de su esposo fueran tasados y restituidos hasta alcanzar dicho valor; petición que no le fue concedida hasta marzo de $1717 .{ }^{33}$ Respecto a don Fabián consideramos que la opción más lógica es que se encontrase en el exilio y, aunque no lo hemos podido localizar en los listados de extrañados, parece que testó en Génova en 1721 (Cerdà, 2012:I,469), por lo que suponemos que allí se estableció tras la caída de Barcelona.

\section{Don Carlos Berenguer de Cucaló y Puertolas (1662-1731)}

Hijo de Felipe Berenguer, natural de Sagunto, y Gertrudis Puertolás, de Valencia, recibió el hábito como caballero de Montesa en 1682 (Cerdà, 2012: II, 44-45). Poco ha trascendido sobre su colaboración con el gobierno austracista, aunque sí lo suficiente para entender que la Orden se viese obligada a procesarlo. De hecho, en marzo de 1707 fue designado teniente y capitán general del maestrat vell de Montesa dellà coll de la Garrofera ${ }^{54}$, cargo que juró frente al lugarteniente Cardona el día 8 de dicho mes, frente a los también austracistas y caballeros de Montesa don Fabián Cerdà y don José Almunia. Tras la batalla de Almansa se estableció en Barcelona y la Orden,

52. ÖSTA, HHStA, Italien-Spanischer Rat, Supremo Consejo de España, k. 2-3, ff. $628 \mathrm{r}-629 \mathrm{v}$.

53. ARV, Clero, Montesa, c. 2348, exp. 3.

54. En el proceso también se hace referencia a él como lugarteniente y capitán del Maestrazgo Viejo, así como gobernador de San Mateo.

Ediciones Universidad de Salamanca / @®@@ Stud. his., H. ${ }^{a}$ mod., 42, n. 2 (2020), pp. 365-400 
mediante sentencia de 29 de agosto de 1708, le aplicó las mimas penas que hemos expuesto con anterioridad ${ }^{55}$. De su patrimonio Montesa consiguió recaudar, entre 1708-1725, alrededor de 7.000 libras ${ }^{56}$ obtenidas del arrendamiento de una heredad situada en la villa de Murviedro -por un precio anual medio de 320 libras- y de las rentas de la villa de Alberique -con un valor medio de 50 libras anuales- ${ }^{.7}$ Desconocemos la trayectoria del personaje con posterioridad a la rendición de Barcelona. Aunque la opción más lógica es que optase por el extrañamiento, los autores que han reproducido los listados de exiliados no constatan su presencia en ellos.

Frey José Vilanova y Vilanova (ca. 1659-ca. 1710)

Freile montesiano nacido en San Mateo, hijo de José Vilanova -quien había ejercido varios oficios municipales en dicha localidad-y Agustina Vilanova, ingresó en la Orden en 1679 y llevó a cabo estudios que le valieron el grado de licenciado, aunque tampoco sabemos con exactitud en qué tipo de formación (Cerdà, 2012: III, 337-338). En 1697 el lugarteniente Cardona lo designó rector de su localidad natal, lugar desde el que llevó a cabo su actividad filoaustracista. Según los testimonios entre 1706-1707 actuó como gobernador militar de dicha villa, hasta que fue substituido por don Carlos Berenguer. Una situación de poder que había aprovechado para llevar a cabo el secuestro de los bienes a los vecinos borbónicos. En cambio, pese a su proximidad a la frontera catalana, nunca llegó a exiliarse, sino que su disidencia fue castigada con la prisión en el castillo de Peñiscola junto a don Luis Mas ${ }^{58}$. En este caso también nos encontramos ante un sumario inconcluso, del que solo se conserva la recepción de testigos en mayo de 1709. Creemos que, al estar ya preso, la Orden prefirió priorizar otros procesos, por lo que parece probable que el fraile muriese estando privado de su libertad.

Don Antonio Mas y Borrás (1659-c.a.1726)

Hijo de Martín Mas y Sans, subrogado de gobernador de Castellón, y Felipa Borrás, natural de Benicarló, don Antonio formaba parte de una familia con una consolidada situación económica gracias a su dedicación comercial e inversora; pues los Borrás llevaban décadas ejerciendo como unos de los principales exportadores

55. ARV, Clero, Montesa, c. 2424-25, exp. 24.

56. Según el libro de cuentas de la Orden la cantidad total recaudada fue de 6.537 libras, pero nuestros cálculos aumentan la cifra a 7.386. También aparece señalada la existencia de una casa y una huerta que fueron arrendadas por un tiempo, pero no disponen la duración del mismo ni la cantidad obtenida.

57. ARV, Clero, L. 2546.

58. ARV, Clero, Montesa, c. 2426, exp. 13.

Ediciones Universidad de Salamanca / @®@@ Stud. his., H. ${ }^{a}$ mod., 42, n. 2 (2020), pp. 365-400 
de vino de Benicarló. Esta actividad supuso la base del crecimiento económico de la casa, aspecto al que debemos sumar un importante patrimonio inmueble centrado en la baronía de Ensaloni (Castellón) y la propiedad de unas 17 casas repartidas entre Valencia, Càlig y Castellón, la mayoría de las cuales estaban arrendadas. De esta manera, consiguieron reunir un importante capital acumulado -valorado en unas 43.200 libras- que les permitió invertir en actividades financieras y, por consiguiente, incrementar su hacienda. De hecho, don Antonio contaba con un patrimonio valorado en 83.563 libras $^{59}$ derivadas mayoritariamente de la carga de censales. Por tanto, el personaje gozaba de una situación privilegiada que le facultó para, por un lado, ingresar en la Orden de Montesa en 1690 y, por otro, llevar a cabo servicios a la Monarquía tanto militares como en el ámbito municipal, consolidando así su posición e influencia social (Cerdà, 2012: II, 460; López, 2015: 378-379).

$\mathrm{Al}$ comenzar el conflicto sucesorio en suelo valenciano, el virrey borbónico quiso organizar la defensa del Maestrazgo, al considerar la zona como objetivo aliado, dada su cercanía a Cataluña. Incluso ya se empezaban a detectar en Vinaroz las primeras actividades proaustracistas, por lo que se decidió constituir una junta que asegurase la fidelidad de la costa norte valenciana y refrenase la incipiente desafección. Borrás fue designado uno de sus integrantes (Pérez, 2009: II, 84-85), lo cual podría indicarnos una inicial vinculación borbónica que revirtió -si es que existió- con la entrada de las tropas aliadas en la capital del Reino. A partir de este momento el personaje se involucró de lleno en los hechos de armas austracistas del territorio valenciano, llegando a constituir y pagar un regimiento de unos 500 hombres que él mismo capitaneó y que dispuso al servicio de Carlos III y su causa. Una guarnición que tenía su cuartel en la calle Zaragoza (Valencia) y de la que se constata una especial importancia en los sitios de Murcia y Cartagena ${ }^{60}$. Resulta evidente que don Antonio comprometió su patrimonio en favor del Archiduque, quién lo recompensó con la designación de coronel de un regimiento de caballería constituido por Peterborough, el 13 de marzo de $1706^{61}$.

Pero tras la rendición de Valencia a las tropas borbónicas y una vez consolidado el dominio de Felipe $\mathrm{V}$ en el Reino, la Orden de Montesa abrió un proceso criminal contra su persona, pues, obviamente, la actividad de Mas no iba a pasar desapercibida. Así, en enero de 1709 iniciaron las averiguaciones mediante las que constataron tanto su actividad militar como su huida a Barcelona tras la batalla de Almansa, donde continuaba ejerciendo el cargo de coronel para el que había sido nombrado. La sentencia en su contra por contumacia, ayuda a los enemigos y falta al juramento de

59. ÖSTA, HHStA, StAbt, Spanien Varia, k. 50-3, ff. 224r-229v.

60. Sobre la actuación militar del personaje al frente de las milicias austracistas ver Hernández, 2019; 84-87.

61. ÖSTA, HHStA, StAbt, Spanien Varia, k. 50-3, ff. 219v. ARV, Clero, Montesa, c. 2428-29.

Ediciones Universidad de Salamanca / @@@ Stud. his., H. ${ }^{a}$ mod., 42, n. 2 (2020), pp. 365-400 
fidelidad a Felipe V se publicó el 15 de febrero de 1710, condenándolo a las mismas penas que el resto de caballeros procesados ${ }^{62}$, y como en los demás casos la única sanción que llegó a materializarse fue la incautación de su patrimonio. Según el ya citado libro de cuentas solo consiguieron reunir 3.255 libras 13 sueldos y 9 dineros por el arrendamiento del molino de Ensaloni entre 1710-1723. ${ }^{63}$ En este sentido es muy llamativo que un personaje con un patrimonio valorado en más de 100.000 libras -antes del conflicto- solo le fuesen decomisadas las rentas del molino y no las pertenecientes al resto de casas ni la alta cantidad cargada en censales. Ciertamente poco sabemos de su familia, solamente que tuvo, al menos, un hermano mayor, Luis Borras, que también recibió el hábito de Montesa y del que se sabe que estuvo preso en 1707 en el castillo de Peñíscola por austracista junto al rector de San Mateo, fray José Vilanova (Cerdà, 2012: II, 462), de quién ya hemos hablado. Desconocemos que pasó exactamente con los bienes de su Casa, aunque en el memorial que presentó al Consejo de Aragón en diciembre de 1711 exponía la difícil situación económica que atravesaba. Por un lado, la mayor parte de sus bienes habían sido saqueados por las tropas borbónicas, causándole una gran cantidad de pérdidas tanto en el producto de las cosechas como en el número de cabezas de ganado. Por otro lado, había invertido gran parte de su patrimonio en la causa austracista, especialmente en la conformación del regimiento que él mismo capitaneaba -al que no solo pagaba los salarios, sino también todo lo relacionado con su equipamiento- y en la recluta de centenares de hombres que se sumaron a otros batallones, haciéndose cargo de todos los dispendios y sin recibir ayudas de costa ${ }^{64}$.

Asentado en el Principado continuó su labor militar y trató de encontrar una solución a su precariedad económica, al presentar el citado memorial y relatar su hoja de servicios y las pérdidas sufridas por su fidelidad a Carlos III. Con todo, pretendía que le fuese concedido un título de nobleza ligado a una baronía de al menos 300 vecinos en el reino de Valencia. El Consejo de Aragón, en consulta de 27 de abril de 1712 declaró la viabilidad de la merced, teniendo en cuenta el haber contribuido «con gran zelo en muchas operaciones» así como el padecer «grandes trabajos y menoscabos, abandonando su casa y quantioso patrimonio», opinión que también compartió la Emperatriz al aprobar la merced en abril de 1712 aunque con el requisito de que el título y baronía fueran concedidas en el reino de Aragón ${ }^{65}$. Una concesión que probablemente nunca llegó a hacerse efectiva. En la misma línea tampoco sabemos exactamente cuál fue su destino después de 1714, pues no lo hemos podido localizar entre los listados de exiliados, aunque seguramente esta

62. Idem.

63. ARV, Clero, L. 2546.

64. ÖSTA, HHStA, StAbt, Spanien Varia, k. 50-3, ff. 221v-223r.

65. Idem, ff. $217 \mathrm{r}-223 \mathrm{v}$. 
fue su suerte, pero no su voluntad. De hecho, hacia 1716 presentó una solicitud de perdón a Felipe $\mathrm{V}$ con la intención de poder volver a sus dominios (Saavedra, 2000: 502), una pretensión que no le fue concedida, por lo que debió pasar algunos años en el destierro, probablemente hasta 1725. En definitiva, resulta evidente que nos encontramos ante un caso bastante excepcional, pues no parece que don Antonio, a pesar de la gran inversión económica y personal en la causa austracista, tuviese una compensación efectiva por sus esfuerzos, pues ni ostentaría la titularidad de un señorío, ni aparece en los listados de exilados con pensión. Así las cosas, pediría permiso para retornar a dominios hispánicos, lo cual podría ser interpretado tanto como la causa por la que no disfrutó de las mercedes imperiales como la consecuencia de experimentar la difícil coyuntura del exilio, que lo motivase a tratar de retornar a Castellón para recuperar sus bienes ${ }^{66}$.

\subsection{Los freiles al servicio de la causa austracista. Cargos, exilio y uso del púlpito}

Frey Gaspar Zapata y Ivars (1671-ca. 1722)

Hijo del familiar del Santo Oficio Juan Zapata Ledesma y su esposa Eutimia Ivars, ingresó en la Orden de Montesa en 1686. Ya como fraile se licenció y obtuvo la categoría de maestro en Artes, así como la condición de examinador en la Universidad de Valencia. Como freile montesiano cabe destacar su nombramiento como rector de la Salsadella en 1699 y posteriormente de Benasal, que ejerció entre 17011713 (Cerdà, 2012: III, 68), ambos bajo la lugartenencia de Cardona. Su inclinación filoaustracista queda patente en el proceso criminal que la misma Orden inició en su contra en mayo de 1708, el cual resta inacabado. Gracias a esta documentación hemos podido conocer que el 10 de marzo de 1707 juró ante el conde de Cardona como rector del Real Colegio de San Jorge, por lo que, para ejercerlo, debió renunciar a la rectoría de Benasal. Aceptar y jurar un cargo para el que había sido designado por Carlos III era motivo suficiente para ser considerado traidor e infiel a Felipe V, y más si tras la batalla de Almansa se había refugiado en Barcelona, donde según un testimonio, había mantenido un contacto constante con el Conde de Cardona ${ }^{67}$. Como decimos, no sabemos en qué momento se publicó su sentencia, pero sí que esta existió y que entre las penas dispuestas se encontraba la confiscación de sus bienes. De hecho, según el libro de cuentas le fueron incautadas dos casas situadas en Valencia, concretamente en la calle de la Sombrería, perteneciente a la parroquia de Santa Catalina. La Orden procedió a arrendar la vivienda, por lo que entre

66. Según el estudio de Cerdà (2012: I, 470), se encontraba prisionero fuera de territorio hispánico cuando presentó la petición de retorno.

67. ARV, Clero, Montesa, c. 2424-25, exp. 29.

Ediciones Universidad de Salamanca / @®@@ Stud. his., H. ${ }^{a}$ mod., 42, n. 2 (2020), pp. 365-400 
MARIA SALAS BENEDITO

INFIDELIDAD Y PUNICIÓN. CABALLEROS Y FREILES AUSTRACISTAS

ANTE EL TRIBUNAL DE LA LUGARTENENCIA GENERAL DE MONTESA

1708-1721 ${ }^{68}$ pudieron recaudar entre 430-455 libras ${ }^{69}$ como cantidad total. Tras la muerte de frey Zapata en 1722, encontrándose probablemente en el exilio, las dos casas fueron devueltas a su heredero, el ciudadano José Juan Bautista Isidoro $Z_{\text {Zapata }}{ }^{70}$. Como vemos es un caso peculiar en comparación con el resto de religiosos, de hecho, es el único que sufrió la incautación, lo cual nos lleva a pensar que gozaría de una situación económica qué si le permitiría el extrañamiento, aunque, de ser así, no conocemos donde se estableció tras 1714.

Frey José Amposta (¿̨-1730)

José Amposta nació en Castellón de la Plana, fruto del matrimonio entre José Amposta y Teresa Servera. Ingresó en la Orden en 1701, siendo ya rey Felipe V, e inició su formación hasta obtener el título de licenciado, aunque tampoco se conoce en qué materias. En el contexto del conflicto sucesorio abandonó el convento para establecerse en el Palacio del Temple, por lo que, una vez reestablecido el dominio borbónico, el nuevo lugarteniente general le ordenó retornar a Montesa. El religioso no cumplió el mandato de su superior, sino que marchó a Barcelona, donde se mantuvo hasta 1714. Tras la caída de la ciudad, voluntariamente se presentó en el castillo de Montesa e inmediatamente fue privado de su libertad, aunque el proceso judicial en su contra no se inició hasta abril de 1718. Siete meses más tarde fue publicado el laudo en su contra, mediante el cual solamente fue condenado a dos meses más de prisión y el pago de los costes del juicio, pues el tribunal dispuso que no se constataban actos de sedición, sino únicamente la falta a la obediencia ${ }^{71}$. Con todo, parece que no le fue difícil recuperar la confianza de la Orden, pues en 1725 fue nombrado rector de Silla, cargó que ostentaría hasta su defunción (Cerdà, 2012: III, 13).

Frey José Cambra (1660-1729)

Nacido en Vinaroz e hijo del mercader Francisco Cambra y su esposa María Bayarri, recibió el hábito de Montesa 1679 y su trayectoria dentro de la Orden estuvo

68. Cabe destacar que, según las fechas del secuestro, la sentencia debió publicarse en 1708, mismo año en que inició el proceso, probablemente hacia el mes de octubre, pues la primera cifra de arrendamiento de una de las casas data del día 25 de ese mes.

69. Una de las casas fue arrendada por 28 libras anuales aproximadamente, mientras que la otra vivienda se arrendó con un precio fijo de 8 libras anuales. Según el libro de cuentas la cantidad total se sitúa en poco más de 455 libras, aunque según nuestros cálculos fue de aproximadamente 431.

70 ARV, Clero, L. 2546.

71. ARV, Clero, Montesa, c. 2348, exp. 4.

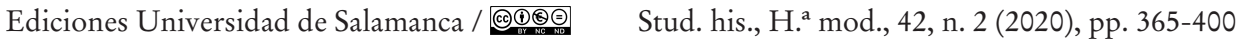


altamente ligada a frey Hipólito Samper, de quien fue discípulo. Tras doctorarse en Derecho Canónico por la Universidad de Valencia se trasladó a la Corte junto a su maestro con la intención de ayudarle en la elaboración de un libro sobre la Real Capilla. En este contexto el lugarteniente Cardona lo designó rector de las Cuevas en 1694, cargo que rechazó para quedarse en la Corte y que le valió un enfrentamiento con su superior en la Orden. Nunca llegó a ocupar dicha rectoría, pero en 1697 fue nombrado catedrático de Teología Moral en substitución del también montesiano frey Antonio de Benavides. En 1701 lo encontramos como rector de la parroquia de Montesa, puesto al que se asociaba la dignidad de prior de San Sebastián (Cerdà, 2012: I, 482-484; III, 65-66). Así las cosas, en el contexto del conflicto sucesorio se trasladó a Valencia y en los últimos momentos de dominación austracista se estableció en Vinaroz, de donde pasó al Principado tras conocer las noticias de la derrota en Almansa, donde permaneció entre 1707-1713, por lo que la Orden, lógicamente, lo inculpó. Con todo, acabó presentándose voluntariamente frente al convento de Montesa en 1714, donde fue encarcelado. La causa judicial inició en agosto de 1715 y el acusado trató de demostrar que siempre se había mantenido fiel al Borbón. Según Cambra en 1706 viajó a Valencia para pedir al lugarteniente general y virrey que las tropas austracistas dejasen de presionar y violentar a la población de Montesa. Estando en la capital supo que la villa había sido saqueada, por lo que decidió no retornar y pidió licencia para ausentarse a Vinaroz con motivo del fallecimiento de su madre. Tras los sucesos de Almansa, temeroso de la represión, decidió pasar a Tortosa junto con sus hermanos y de allí a Barcelona, escapando de las epidemias que abrasaban el sur del Principado. Finalmente, en 1713 fue encarcelado en Tortosa, situación en la que se mantuvo prácticamente un año, consiguiendo retornar a territorio valenciano. Evidentemente nos encontramos ante un caso de dudosa filiación austracista y lo mismo parece que entendieron los de Montesa, por lo que, al publicar su sentencia en 1718, únicamente fue condenado a dos meses más de prisión y la obligación de pagar con su sueldo de sacerdote tanto los gastos de su alimentación y manutención como los costes del proceso ${ }^{72}$. Como en casos anteriores, el religioso acabó reconciliándose con la Orden pues lo encontramos ostentando la rectoría de Montesa hasta 1723, cuando fue nombrado rector de Carpesa, cargo que ocupó hasta el momento de su muerte en septiembre de 1729 (Cerdà, 2012: I, 484; Ximeno, 1749: 218).

72. Idem. Cabe destacar que la sentencia aparece sin fecha dentro del proceso, si bien Cerdà recoge que el rey aprobó su publicación en 1717.

Ediciones Universidad de Salamanca / @®@@ Stud. his., H. ${ }^{a}$ mod., 42, n. 2 (2020), pp. 365-400 
Frey Rafael Pisà y Cerdà (1682-1748)

Natural del Grau de Valencia, este freile montesiano fruto del matrimonio entre Rafael Pisà -familiar de la Inquisición- y María Cerdà, recibió el hábito de Montesa en 1700, aunque no ejerció ningún cargo dentro de la Orden antes ni durante el conflicto sucesorio, más allá de estar licenciado y ostentar la posición de conventual en la misma (Cerdà, 2012: I, 481 y 491; III, 234). Tampoco queda constancia sobre una posible actividad relevante al servicio del Archiduque, salvo el hecho de exiliarse a Barcelona tras la derrota de las fuerzas aliadas en Almansa. Sin embargo, como en los casos anteriores, decidieron procesarlo criminalmente y condenarlo, aunque con una pena bastante diferente a la de otros austracistas o sospechosos de serlo. Se expidió una orden de captura contra él, de forma que tras apresarlo fuese conducido a un presidio africano, lugar en el que se mantendría por espacio de cuatro años, ejerciendo su ministerio y sirviendo en el hospital del mismo. Además, debía pagar una multa de 200 ducados a la iglesia del Temple y hacerse cargo del monto económico que había supuesto el proceso judicial. Respecto a su posición dentro de la Orden, le fueron retiradas las gracias y mercedes de las que gozaba -las cuales no conocemos- pero no su hábito ${ }^{73}$. En última instancia es necesario comentar que no sabemos si acabó cumpliendo su condena, pero sí que en 1722 fue nombrado beneficiado de San Miguel en la capilla de Nuestra Señora de los Ángeles, pasando en 1732 a ocupar la dignidad de sacristán mayor del convento de Montesa, tras la jubilación de frey Antonio Cruz. Entre la ostentación de ambos cargos, hacia 1728 partió a Viena, con permiso de la Orden, parece que para atender a un hermano suyo que se encontraba en el exilio, volviendo a tierras valencianas en 1732. Finalmente murió en 1748, consecuencia de unos terremotos acaecidos en la población de Canals (Cerdà, 2012: III, 234-235); y, por lo que parece, reconciliado con la Orden, ya que carecería de sentido un permiso para trasladarse al Imperio si no tuviesen seguridad respecto a su fidelidad.

Frey Juan Selma (¿’-1718)

Natural de Ares del Mestre e hijo de Juan Selma y Isabel Roca, ingresó en Montesa en 1670 para profesar un año después. Rector de Adzaneta, fue acusado de perseguir y amenazar a los borbónicos de la villa y los lugares vecinos, así como de usar el púlpito para ganar adeptos a la causa imperial; incluso se estimaba que había cogido las armas para participar, junto a un contingente de más de 300 personas, en un intento de saqueo contra la población de Benasal, con el objetivo de represaliar a los filipistas que habían conseguido su rendición. Unas acciones que lo llevaron a

73. ARV, Clero, Montesa, c. 2424-25, exp. 26.

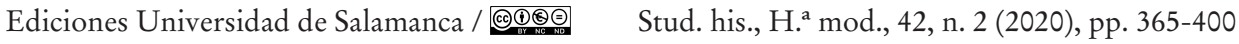


abandonar su rectoría cuando Adzaneta cayó nuevamente bajo dominio borbónico, por miedo a las represalias, aunque la Orden consiguió capturarlo y encarcelarlo en la Torre del Temple. En su defensa, Selma, no negaba haber apoyado a Carlos III, aunque argüía que lo hizo por obediencia, exponiendo: «(...) porque el conde de Cardona, lugarteniente general que fue en aquel tiempo de la Religión, lo mandava así». Un intento, suponemos, de mostrar su arrepentimiento y presentar sus actuaciones como la debida obediencia al superior de la Orden y no como una inclinación personal. Del mismo modo también negaba la persecución de los vecinos borbónicos, así como su participación en los hechos de Benasal. Con todo, nos encontramos nuevamente ante un proceso inconcluso, aunque basándonos en los paralelismos existentes con otros sumarios, creemos que debió pasar un tiempo más en la prisión para posteriormente volver a hacerse cargo de la titularidad de la rectoría ${ }^{74}$. De lo contrario no tendría sentido que Cerdà (2012: III, 297-298) atestiguase que ostentó dicho cargo hasta el momento de su muerte.

\section{Frey Vicente Correger (1685-1747)}

Nacido en Onteniente fruto del matrimonio entre Vicente Correger y Esperanza Cresencia, obtuvo el hábito montesiano en 1701 y al poco tiempo se convirtió en colegial (Cerdà, 2012: III,84). Este freile, pertenecía a una familia claramente vinculada con el movimiento austracista, motivo por el cual la Orden sospechó de su fidelidad y trató de controlar sus movimientos. Con esta intención, en junio de 1707, el lugarteniente general Valltera, expidió una orden que le prohibia abandonar el colegio de San Jaime; aunque, al conocer el mandato, decidió escapar y dirigirse a su ciudad natal, para posteriormente establecerse en Agus, aún austracista. En ella se mantuvo hasta la entrada de las tropas borbónicas, momento en que consiguió ponerse a recaudo en Alicante, donde seguía en 1708. Así las cosas, a principios de ese mismo año el tribunal montesiano decidió iniciar un sumario en su contra, acusándolo de haber faltado tanto a la debida fidelidad al monarca como a las obligaciones de su estado. En este sentido, la supuesta disidencia de Correger se basaba en haber expuesto públicamente su repulsa hacia los partidarios de Felipe V, así como animar a los austracistas a perseverar en sus esfuerzos, además de haber abandonado el colegio para situarse en territorio de dominación aliada. Como vemos, el personaje siguió una trayectoria similar a otros religiosos, aunque no conocemos si también padeció la pena de prisión debido a que el proceso no cuenta con una sentencia. Sea como fuere, sí ha trascendido la noticia de su indulto, aunque sin especificar ni el momento ni los motivos que lo hicieron merecedor de dicha gracia ${ }^{75}$.

74. ARV, Clero, Montesa, c. 2426, exp. 12.

75. ARV, Clero, Montesa, c. 2424-25, exp. 6 y 11.

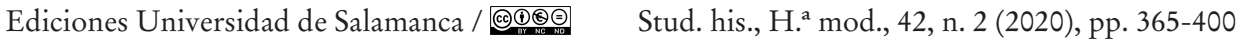


Frey Tomás Gozalbo y Clavel (1669-1717)

Oriundo de Valencia, fruto del enlace de Miquel Gozalbo -familiar del Santo Oficio- y María Clavel, ingresó en la Orden en 1688 y obtuvo el grado de licenciado (Cerdà, 2012: III, 140). Rector de Culla, en 1707 recibió un pliego del juez del breve apostólico que lo instaba a personarse en Valencia. Decidió no acatar la orden, por lo que dejó la población y se trasladó a Morella, aún proimperial. En este lugar se mantuvo hasta su rendición y posteriormente se estableció en Tortosa, donde -según el procesado-fue consciente de su erróneo posicionamiento y resolvió no escapar del asedio al que fue sometida la ciudad. En este contexto, el duque de Orleans había prometido indulto a todos los foráneos que se encontraban en el lugar, por lo que confiando en el contenido de las capitulaciones decidió regresar a territorio valenciano y presentarse en el convento de Montesa. Inmediatamente la Orden lo encarceló y 15 meses más tarde, en abril de 1709, iniciaron el sumario en su contra. En sus confesiones ante el tribunal, negó haber cometido las acciones a favor de la causa carolina de la que se hacían eco los vecinos de Culla y nombró como su procurador al notario Francisco de Castro. Este último defendía que las acusaciones no podían demostrarse conforme al derecho, sino que los testimonios estaban emitiendo juicios de valor sobre el inculpado, por lo que consideraba necesario un nuevo interrogatorio. De esta manera consiguió demostrar que no existían pruebas suficientes para incriminar a su representado, a quien, con la publicación de la sentencia (1714), se le dictaron tres meses más de prisión y el pago de los costos procesales. Posteriormente retomaría sus funciones en Culla, eso sí, bajo la estrecha vigilancia del lugarteniente ${ }^{76}$.

Frey Jerónimo Domínguez y Puerto (ca. 1647-ca. 1714)

Hijo de Jerónimo Domínguez y Josefa Puerto, originarios de Bocairente, le fue concedido el hábito montesiano en 1665 y profesó un año después. Dentro de la Orden obtuvo el grado de licenciado y ostentó las rectorías de la Salsadella, Rosell y, finalmente, de Beniarrés, destino que se encontraba sirviendo al estallar el conflicto (Cerdà, 2012: III, 91-92). En 1709 el tribunal montesiano lo denunció criminalmente, aunque debemos destacar que nos encontramos ante un sumario distinto, en tanto en cuanto, al mismo tiempo que se le acusó de filoimperial también fue relacionado con la realización de prácticas inmorales. Por un lado, parece ser que Domínguez había contribuido a la existencia de un alto porcentaje de austracismo entre los vecinos de la población, sirviéndose tanto del púlpito como de los negocios financieros de su familia. Trató de convencer a sus feligreses de que la voluntad de Dios era ver

76. Ibid., c. 2428-29, exp. 8. 
sentado en el trono de la Monarquía Hispánica a Carlos III y todas las tardes, al rezar el rosario en el templo, ofrecía un Ave María por el Archiduque y los buenos sucesos de su causa y armas; incluso los había alentado a unirse voluntariamente a las guarniciones de los austracistas, prometiéndoles dinero y vituallas de alimento y municiones. Los testigos defendían que coaccionó a muchos vecinos para apoyar a los aliados, sirviéndose de las deudas que tenían contraídas con él. Así mismo, parece que mantuvo un trato cercano con los miqueletes e incluso les encomendó la represión de unos cuantos vecinos de Beniarrés que se mantenían fieles a Felipe V. Por otro lado, los testigos aseguraban que el sacerdote no cumplía con sus obligaciones de prédica y administración de los sacramentos con la regularidad requerida, ni se preocupaba por el buen estado de los objetos de culto. Acusaciones a las que sumaban el ejercicio de actividades comerciales y la falta de moralidad del religioso, ni vestía ni se expresaba con decoro y, además, parecía mantener una relación ilícita con una mujer casada de la villa ${ }^{77}$.

No conocemos muy bien qué trayectoria siguió después que Beniarrés prestase obediencia a Felipe V, aunque en 1709 ya se encontraba preso. Al declarar negó todas las acusaciones y trató de demostrar su fidelidad al Borbón, argumentando que había prestado ayuda a las tropas y había sido víctima de los miqueletes. Por otro lado, aseguraba que si había rezado por Carlos III fue para protegerse, disimulando su fidelidad al otro candidato. Respecto a las malas prácticas, desmintió todos los cargos y aseguraba que no realizaba ninguna actividad comercial o financiera, ya que eran negocios que habían pertenecido a su hermano y que, tras su muerte, estaba gestionando su cuñada. Como vemos una versión totalmente contradictoria que también apoyó su procurador, Timoteo Giberto, quien defendía la parcialidad de los testimonios en base a una enemistad preexistente entre el imputado y otro religioso del lugar, mosén Bartolomé Vilaplana. Requirió la recepción de nuevos testigos y consiguió demostrar que parte de las acusaciones no parecían reales, especialmente las relacionadas con la práctica religiosa y moral. Por otro lado, continuaban tachándolo de disidente, aunque no pudieron aportar pruebas fehacientes. Con todo, el sumario también aparece incompleto, por lo que no conocemos si llegó a pronunciarse una sentencia en su contra ${ }^{78}$. Aun así, consideramos importante constatar la importancia de un proceso que hace patente una vertiente más social del conflicto civil, pues parece evidente que algunos vecinos aprovecharon el contexto de persecución de la disidencia política para tratar de perjudicar al acusado, con quien ya existían rencillas anteriores ${ }^{79}$.

77. Ibid., c. 2424-25, n. ${ }^{\circ} 1$.

78. Según recoge Cerdà (2012; I, 493) en 1710 fue condenado a tres años de reclusión en el convento de Montesa, así como a la paga de una multa de 200 libras, una información que no se encuentra en el proceso consultado.

79. ARV, Clero, Montesa, c. 2424-25, n. ${ }^{\circ} 1$.

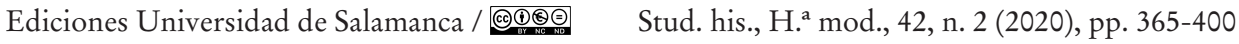


MARIA SALAS BENEDITO

INFIDELIDAD Y PUNICIÓN. CABALLEROS Y FREILES AUSTRACISTAS

ANTE EL TRIBUNAL DE LA LUGARTENENCIA GENERAL DE MONTESA

Frey Félix Vicente (1671-1722)

Nacido en Valencia, descendiente de Basilio Vicente y Francisca Alegre, ingresó en Montesa en 1671, donde alcanzó el grado de Doctor y ostentó las rectorías de Albocácer, Vinaroz y, desde 1702, de Cervera del Maestre (Cerdà, 2012: III, 331). Su posicionamiento también resultó un tanto ambiguo para la Orden, que decidió iniciar el juicio en su contra de 1710. Principalmente fue acusado de acoger en su casa a un alférez y dos miqueletes en tiempos de dominación austriacista, a quienes habría dejado las llaves de la iglesia para saquear los bienes que los vecinos borbónicos habían acogido a sagrado antes de huir a Peñíscola, escapando de las represalias. El religioso, también preso al tiempo de la apertura del sumario, declaró su intachable fidelidad a Felipe $\mathrm{V}$ y explicaba que había recibido en su casa a los miqueletes bajo presión de las autoridades municipales de la villa, accediendo a cambio de una salvaguardia que garantizase la protección de las personas que se habían refugiado en su casa, sobre todo mujeres. Su procurador, Timoteo García, pidió un nuevo interrogatorio, con la intención de demostrar que las imputaciones no podían ser probadas conforme a derecho, resaltando que no estaba en manos del religioso impedir la entrada de miqueletes en la población, así como la confianza de los vecinos borbónicos en su persona, pues habían dejado sus bienes en la iglesia. Gracias al nuevo interrogatorio, la Orden dictaminó que existían muchas dudas acerca del caso, por lo que en la sentencia únicamente le fue aplicada una pena mínima, tres meses más de prisión y el pago de los costes del proceso ${ }^{80}$.

\section{A MODO DE CONCLUSIÓN: LOS CAMINOS DE LA DISIDENCIA}

El análisis de los diferentes casos requiere una puesta en común que nos permita establecer una serie de conclusiones en base a las diferentes trayectorias seguidas por los montesianos que tomaron partido por el Archiduque. En primer lugar, consideramos importante atender a la forma en que se llevó a cabo la represión por parte de la Orden. Como hemos visto, contamos con 21 procesos y 14 sentencias. La mayor parte de estos -19- iniciaron entre 1708-1710, de los cuales se publicó el laudo de 9 dentro del mismo período; lo cual demuestra la premura de la Orden en castigar la disidencia. Aun así, existen diferencias significativas. Por un lado, los juicios contra los caballeros tuvieron una resolución mucho más temprana, pues todos -excepto en el caso de L. Pasqual- contaron con una sentencia pasados un promedio de siete meses desde el momento en que fueron acusados por el fiscal. Estimamos que dicha rapidez estuvo motivada por dos aspectos fundamentales: la voluntad de penar la rebeldía con la incautación de los bienes y la ausencia del

80. Ibid., c. 2354, n. $^{\circ} 2$.

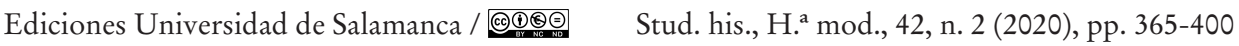


imputado, lo cual impidió que este se presentase a declarar o designase procuradores que, presentando alegaciones, alargase el transcurso del pleito. Aun así, es importante recordar que finalmente la Orden no pudo beneficiarse de los secuestros ni de la retirada de los cargos dentro de la misma, pues todos los patrimonios estaban altamente comprometidos y las cantidades que consiguieron reunir tuvieron que emplearlas, bien en pagar a los acreedores, bien en devolverlos total o parcialmente a las esposas de los condenados, en concepto de sus dotes. Del mismo modo, tampoco pudieron sacar provecho de las dignidades retiradas, pues el gobierno borbónico se sirvió de ellas para recompensar la fidelidad de quienes los habían apoyado durante el conflicto. Por otro lado, las vistas de los religiosos se alargaron mucho más en el tiempo y aproximadamente la mitad se encuentran sin sentencia. Creemos que esto se debe a que prácticamente todos se encontraban en la prisión al inicio de los mismos y, como entre las penas impuestas no parece ser común la confiscación, la Orden pudo optar por alargar el proceso, manteniéndolos más tiempo privados de su libertad. Solo el caso de G. Zapata, condenado al decomiso, escapa de las directrices aplicadas al resto de freiles, aunque también su trayectoria difiere, pues junto con Benavides, Menor y Vilanova, constituyen los únicos religiosos que obtuvieron cargos al servicio del Archiduque. Evidentemente esto demuestra una probada implicación con la causa y requeriría una pena mayor, la misma que suponemos hubiesen sufrido los otros tres personajes, si no hubiesen muerto en una cronología tan temprana. El resto de freiles, por su parte, estuvieron bastante tiempo en la prisión, si bien prácticamente todos acabaron reconciliándose con la Orden y recuperando el ejercicio de sus cargos en la misma.

No podemos obviar la mayor presencia de religiosos entre los procesados, un hecho de difícil interpretación en tanto en cuanto somos conscientes de las diferentes casuísticas a valorar. Entre ellas, y dado que en gran medida se trata de rectores de la Orden, creemos que un aspecto a tener en cuenta es que las sospechas sobre su postura ante los pretendientes al trono pudieron estar muy relacionadas con la localización de las poblaciones en las que servían su oficio. Como es sabido, la mayor parte de las localidades bajo jurisdicción de la Orden se encontraban en la zona del maestrazgo, muy cercanas a la frontera catalana; una zona que despuntó por su mayoritario apoyo a la causa imperial. Aun así, a pesar de que porcentualmente todo parece apuntar a un mayor austracismo entre los religiosos, no deja de ser cierto que es en este grupo en el que más dudas se observan acerca de su verdadero posicionamiento, bien por falta de noticias sobre el camino seguido tras la contienda, bien por la inconclusión de los procesos o incluso porque las acusaciones podían estar más centradas en la actitud de sus feligreses, etc.; inseguridades que prácticamente no aparecen en el caso de los caballeros, en los que su servicio al Archiduque queda más patente. Esto, sumado al hecho de que puedan existir más procesos por localizar, hace que no podamos decantar la balanza sobre un grupo u otro, por el momento. 
Respecto a las trayectorias seguidas por los individuos también existen diversidades dignas de resaltar. Ciertamente existe una tendencia general dentro del grupo: el establecimiento en Cataluña tras los hechos de Almansa. Esta conducta se constata entre todos los caballeros y en gran parte de los freiles (7 de 12) y, en todos los casos, constituye uno de los principales motivos de acusación. Ahora bien, es a partir de este momento cuando se establece el punto de inflexión a la hora de analizar las diferentes formas de proceder según los grupos, pues la actitud seguida por caballeros y religiosos deja de asemejarse tras la caída de Barcelona en 1714. Los primeros optaron mayoritariamente por el exilio, los segundos no quisieron o no pudieron extrañarse, por lo que siguieron un camino muy diferente. Cabe tener en cuenta que hablamos de personas con una posición social y económica mucho más humilde que la del grupo de caballeros, lo que podría explicar las distinciones tanto en su comportamiento como en las sanciones aplicadas, pues no fueron víctimas de la incautación. Otra razón a considerar es el no pesar sobre ellos el «delito» de haber ejercido oficios al servicio de la causa austracista y, a pesar de seguir al Archiduque a tierras catalanas, tampoco se observa una retribución a su posicionamiento. Así, al mantenerse en los dominios borbónicos, fue más fácil para la Orden represaliarlos, ya fuese porque consiguieron capturarlos o porque voluntariamente se presentaron «arrepentidos». En cualquiera de los casos, fueron encarcelados y tras años en prisión consiguieron retomar sus funciones dentro de la misma. Nuevamente el único caso que difiere es el de Zapata, pues no se constata su «reconciliación» con la Orden y, a pesar de la falta de información, todo parece indicar que llegaría a exiliarse.

Instalarse en el Principado, en el caso de los caballeros, supone un paso más en su vinculación con la causa austracista, así como un primer escalón en la percepción de mercedes por parte de Carlos III. Prácticamente todos serán agraciados con cargos y títulos de diferentes categorías, bien ligados a la capacidad graciosa desplegada por el futuro emperador con motivo de acontecimientos relevantes, como fue el caso de su desposorio; bien motivados por la presentación de memoriales al Consejo de Aragón por parte de los interesados. Sea como fuere, el fin último de las concesiones era compensar las pérdidas sufridas por los vasallos consecuencia de mantener su fidelidad a la Casa de Austria, especialmente a nivel crematístico. Por este motivo, encontramos una gran cantidad de dádivas que prometen la concesión de rentas y administraciones de diferentes tipos de bienes, muchas de las cuales nunca pudieron hacerse efectivas porque el Archiduque no mantuvo el dominio sobre los territorios peninsulares. También encontramos mercedes de carácter honorifico, títulos de nobleza y cargos dentro de la Casa Real. Como resulta evidente estas no reportaban un gran beneficio económico, pero sí encumbraban las trayectorias de los agraciados, retribuyendo sus esfuerzos con el tan ansiado ascenso social. Así las cosas, las gratificaciones comportaron el mantenimiento de la fidelidad y esto, sumado a las perdidas y represalias sufridas en territorio valenciano, llevó a los montesianos a apostar por el exilio en 1714, de modo que se constata una reciprocidad evidente

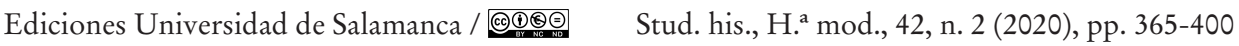


entre las recompensas y el ostracismo. Del conjunto de procesados conocemos del exilio a territorios imperiales de 6, de los cuales 4 se establecieron en Viena y los restantes en Italia. Todos ellos continuaron recibiendo mercedes del emperador, especialmente rentas cobradas sobre Nápoles, pero también títulos nobiliarios y honoríficos. Cabe destacar que no podemos asegurar cuál fue el devenir de Berenguer y Mas, aunque probablemente también apostasen por extrañamiento. Contrariamente, L. Pasqual no abandonó el territorio peninsular, por lo que pasó varios años en las prisiones de la Orden.

En términos generales se observa una misma actitud entre los caballeros procesados, al mantener su compromiso con la causa imperial. Ahora bien, resulta complejo valorar el porqué de su posicionamiento y fidelidad. Aun así, subyace la idea de que seguir al Archiduque fue una apuesta de futuro, la cual, en cierto modo, tuvo sus frutos. Todos obtuvieron cargos de relevancia política y militar a lo largo del gobierno austracista valenciano, lo que podríamos caracterizar como el primer premio a su postura frente al conflicto. Probablemente, en algunos casos, tuvieron la oportunidad de ostentar unos cargos a los que, en otras condiciones, no hubiesen accedido. Evidentemente confiaban en la victoria aliada y, con ella, el mantenimiento de la posición y estatus adquirido durante la contienda; lo que también implicaba preservar la continuidad del sistema político preexistente. Como sabemos, el resultado no fue el que esperaban y tuvieron que enfrentarse a las consecuencias del riesgo adquirido, perdiendo todos sus bienes. Esto no dejó indiferente a Carlos VI, quien constantemente trató de compensar todos los esfuerzos de sus fieles vasallos, pero ¿realmente lo consiguió? o mejor, ¿ los interesados vieron cumplidas sus expectativas? No podemos responder con seguridad a estas preguntas, pues muy difícil generalizar y más al carecer de información sobre sus años de exilio. Resulta evidente que el emperador no los dejó desamparados, pero de ahí a que su apuesta tuviese los resultados esperados, son muchas las variables a tener en cuenta. El único caso que sobresale y del que realmente podemos hablar de una mejora exponencial tanto a nivel de estatus como patrimonial es el del Conde de Cardona, aunque también es cierto que a nivel económico poco podía perder. El resto, también obtuvieron todo tipo de retribuciones, pero es mucho más difícil valorar sus ganancias. Por lo que respecta a su estatus, indudablemente se elevó y los títulos de nobleza constituyen la mejor prueba de ello. Pero el ascenso social no necesariamente tuvo que corresponderse con una estabilidad hacendística. Es cierto que recibieron rentas, pero valorar si estas les permitieron vivir con más o menos holgura es mucho más complejo.

El nexo de conexión entre los dos grupos fue, sin lugar a dudas, su lugarteniente general. Es evidente que el conde de Cardona desempeñó un papel clave en el desarrollo del austracismo valenciano y creemos que, en este sentido, mucho tuvo que ver su posición como virrey y lugarteniente general de Montesa. Esto le

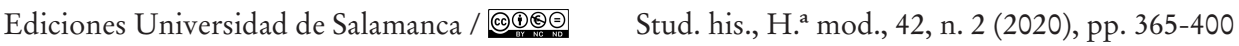


proporcionaba una situación sociopolítica preeminente y, a su vez, muchos contactos con los que tejer su red de poder. Como se puede constatar, los montesianos tuvieron una especial cabida en la misma, pues, de algún modo, le debían una doble fidelidad. Con todo, dicha vinculación con el austracismo y uno de sus máximos exponentes, se tradujo en la obtención de cargos. Así, cuando el virrey Cardona se propuso remodelar la composición social de las instituciones valencianas, eligió a muchos miembros de Montesa, sobre todo caballeros, para encabezarlas y dirigirlas. De este modo, al mismo tiempo que recompensaba su fidelidad, disponía al frente de las instituciones a personas de su confianza. A la vez, también hizo más palpable su «infidelidad» y, con ella, los llevó hacia la punición y el exilio.

\section{BIBLIOGRAFIA}

Alcoberro y Pericay, A. (2002). Exili Austracista (1713-1747). Barcelona: Fundació Noguera, 2 vols.

Andrés Robres, F. (1994). Los decretos de «Nueva Planta» y el gobierno de la Orden de Montesa. En P. Fernández y M. Ortega (coord.), Antiguo Régimen y liberalismo. Homenaje a Miguel Artola (vol. III. pp. 37-47). Madrid: Alianza Editorial.

Andrés Robres, F. (2012). Consecuencias de la Guerra de Sucesión en el señorío de la Orden de Montesa. Las encomiendas según los informes de la década de 1730 y en el contexto de larga duración. En J. Hernando, J. M. López y J. A. Nieto (coords.), La historia como arma de reflexión. Estudios en homenaje al profesor Santos Madrazo (pp. 255-274). Madrid: UAM.

Cerdà i Ballester, J. (2012). Els cavallers i religiosos de l'orde de Montesa en temps dels Austria (1529-1700), 3 vols. (Tesis doctoral). Recuperado de http://hdl.handle. net $/ 10550 / 39368$

Chiquillo Pérez, J. A. (1991). La nobleza austracista en la guerra de sucesión. Algunas hipótesis sobre su participación. Estudis. Revista de historia moderna, 17, 115-148.

Feliu de la Peña, N. (1709). Anales de Cataluña. Barcelona: Imprenta de Juan Pablo Martí, vol. III.

Hernández Ruano, J. (2014), Poderosos pleitos. El señorío de Montesa siglos XVI-XVII. Castellón: UJI.

Hernández Ruano, J. (2019). Guerras paralelas. Propaganda borbónica y austracista en Peñiscola (1700-1706). Castellón: Servicio de publicaciones de la Diputación de Castellón.

León Sanz, V. (1991). Los españoles austracistas exiliados y las medidas de Carlos VI (17131725). Revista de Historia Moderna: Anales de la Universidad de Alicante, 10, 165-176.

León Sanz, V. (1997). La oposición de los Borbones españoles: los austracistas en el exilio. En A. Mestre, P. Fernández y E. Giménez (coords.), Disidencias y exilios en la España Moderna (pp. 469-500). Alicante: Publicaciones Universidad de Alicante.

León Sanz, V. (1998) Patronazgo político en la Corte de Viena: Los españoles y el Real Bolsillo Secreto de Carlos VI. Pedralbes: Revista d'Història Moderna, 18(2), 577-598.

León Sanz, V. (2007). Abandono de patria y hacienda: el exilio austracista valenciano. Revista de historia moderna: Anales de la Universidad de Alicante, 25, 235-256.

Ediciones Universidad de Salamanca / @®@@ Stud. his., H. ${ }^{a}$ mod., 42, n. 2 (2020), pp. 365-400 
León Sanz, V. (2008). El Consejo de Aragón austracista, 1707-1713. En R. Ferrero y L. Guía (coords.), Corts i parlaments de la Corona d'Aragó: unes institucions emblemàtiques en una Monarquia Composta (pp, 239-263). Valencia: PUV.

León Sanz, V. (2014). Un conflicto inacabado. Las confiscaciones a los austracistas valencianos después de la Guerra de Sucesión. Cuadernos Dieciochistas, 15, 195-237.

López Camps, J. E. (2015). Construint la revolta. Política, comunicación i mobilització social en la gènesi de l'austriacisme valencià (Tesis doctoral). Recuperado de http:// hdl.handle.net/10550/50584

Muñoz Rodríguez, J. D. (2007) La Castilla del Archiduque Carlos: movilización social y discurso político en torno al austracismo durante la Guerra de Sucesión. En M. Morales, M. Renom, M. Cisneros (coords.), Actes del Congrés l'Aposta Catalana a la Guerra de Successió (1705-1707) (pp. 305-318). Barcelona: Generalitat de Catalunya, Departament de Cultura i Mitjans de Comunicació, Museu d'Història de Catalunya.

Pérez Aparcio, C. y Felipo Orts, A. (1998). Un drama personal i col·lectiu. L'exili austriacista valencià. Pedralbes: Revista d'bistòria moderna, 18, 329-343.

Pérez Aparcio, C. (2002). Una vida al servicio de la Casa de Austria. Don José Folc de Cardona y Erill, Príncipe de Cardona (1651-1729). Estudis. Revista de Historia Moderna, 28, 421-448.

Pérez Aparcio, C. (2004), Cambio dinástico y disidencia política en el País Valenciano. En E. Serrano (coord.), Felipe V y su tiempo: congreso internacional (vol. 2, pp. 119-149). Zaragoza: Institución Fernando el Católico.

Pérez Aparcio, C. (2009). Canvi dinàstic i guerra de Successió. La fi del Regne de València. València: Edicions 3i4, 2 vol.

Ragón Cardoner, J. (1984) La formació del partit austracista a la Catalunya abans de la Guerra de Successió. En Primer Congrés d'Història Moderna de Catalunya (vol. II, pp. 225-232). Barcelona: Universitat de Barcelona.

Saavedra Zapater, Juan C. (2000). Entre el castigo y el perdón: Felipe V y los austracistas de la Corona de Castilla, 1706-1715. Espacio, Tiempo y Forma, Serie IV, Historia Moderna, 13, 469-497.

Salas Benedito, M. (2019). La trajectòria de don Josep de Cardona i Erill dintre de l'odre de Montesa. Un lloctinent a qui se li va retirar l'hàbit. En E. Guinot, et al. (coords.), Santa María de Montesa. La Orden militar del Reino de Valencia (ss. XIV-XIX) (pp. 375-388). València: PUV.

Sánchez García, S. (2007). Noticias sobre austracistas aragoneses y el secuestro de sus bienes. Revista de historia moderna: Anales de la Universidad de Alicante, 25, 257-302.

Solís, J. (2005). La magistratura autracista en la Corona de Aragón. Manuscrits: Revista d'bistòria moderna, 23, 131-150.

Villamarín, S. (2016). Fidelidad, guerra y castigo. Las instituciones valencianas entre Felipe $V$ de Borbón y Carlos II de Habsburgo. Valencia: PUV.

Ximeno, V. (1749). Escritores del Reyno de Valencia: chronologicamente ordenados desde el año MCCXXXVIII de la christiana conquista de la misma ciudad hasta el de MDCCXLVIII. Valencia: Oficina de Joseph Estevan Dolz, vol. II.

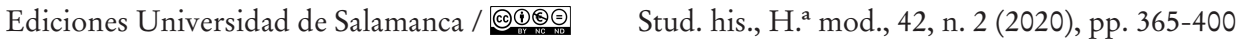

